\title{
Activated Fibroblast Program Orchestrates Tumor Initiation and Progression; Molecular Mechanisms and the Associated Therapeutic Strategies
}

\author{
Go J. Yoshida ${ }^{1, *(\mathbb{D}}$, Arata Azuma ${ }^{2, *(\mathbb{D})}$, Yukiko Miura ${ }^{2}$ and Akira Orimo ${ }^{1, *(\mathbb{D})}$ \\ 1 Department of Molecular Pathogenesis, Juntendo University Faculty of Medicine, 2-1-1 Hongo, Bunkyo-ku, \\ Tokyo, 113-8421, Japan \\ 2 Department of Pulmonary Medicine and Oncology, Graduate School of Medicine, Nippon Medical School, \\ 1-1-5, Sendagi, Bunkyo-ku, Tokyo 1138603, Japan; s7081@nms.ac.jp \\ * Correspondence: go-yoshida@juntendo.ac.jp (G.J.Y.); a-azuma@nms.ac.jp (A.A.); \\ aorimo@juntendo.ac.jp (A.O.); Tel.: +81-3-5802-1039 (G.J.Y.); Fax: +81-3-5684-1646 (G.J.Y.)
}

Received: 25 April 2019; Accepted: 3 May 2019; Published: 7 May 2019

check for updates

\begin{abstract}
Neoplastic epithelial cells coexist in carcinomas with various non-neoplastic stromal cells, together creating the tumor microenvironment. There is a growing interest in the cross-talk between tumor cells and stromal fibroblasts referred to as carcinoma-associated fibroblasts (CAFs), which are frequently present in human carcinomas. CAF populations extracted from different human carcinomas have been shown to possess the ability to influence the hallmarks of cancer. Indeed, several mechanisms underlying CAF-promoted tumorigenesis are elucidated. Activated fibroblasts in CAFs are characterized as alpha-smooth muscle actin-positive myofibroblasts and actin-negative fibroblasts, both of which are competent to support tumor growth and progression. There are, however, heterogeneous CAF populations presumably due to the diverse sources of their progenitors in the tumor-associated stroma. Thus, molecular markers allowing identification of bona fide CAF populations with tumor-promoting traits remain under investigation. CAFs and myofibroblasts in wound healing and fibrosis share biological properties and support epithelial cell growth, not only by remodeling the extracellular matrix, but also by producing numerous growth factors and inflammatory cytokines. Notably, accumulating evidence strongly suggests that anti-fibrosis agents suppress tumor development and progression. In this review, we highlight important tumor-promoting roles of CAFs based on their analogies with wound-derived myofibroblasts and discuss the potential therapeutic strategy targeting CAFs.
\end{abstract}

Keywords: angiogenesis; cancer-associated fibroblasts; extracellular matrix; fibrosis; heterogeneity; interstitial fluid pressure; metabolic reprogramming; transforming growth factor- $\beta$; tumor stiffness

\section{Significant Roles of Fibrosis in Cancer Development}

\subsection{Contributions of Fibrosis to Cancer Development}

Injured epithelial tissues are repaired by the formation of granulation tissues rich in $\alpha$-smooth muscle actin ( $\alpha$-SMA)-positive myofibroblasts (a hallmark of activated fibroblasts), platelets, newly formed blood vessels, macrophages, and other inflammatory cells and extracellular matrix (ECM). The transforming growth factor- $\beta$ (TGF- $\beta$ ) signal pathway is involved in the emergence of myofibroblasts, which contribute to the production of matrix metalloproteinase (MMP) and ECM proteins, such as collagen I, fibronectin and hyaluronic acid [1-4]. The damaged tissues are then degraded and ECM proteins are simultaneously generated de novo [2-5]. Sustained activation of myofibroblasts promotes dysfunctional repair mechanisms, leading to accumulation of fibrotic ECM 
which is rich in collagen fibers and resistant to MMP-mediated degradation $[1,6,7]$. The fibrotic ECM inhibits epithelial cell polarity and stimulates epithelial cell proliferation, which in turn results in conditions allowing tumor formation and development $[8,9]$.

In fact, a growing body of evidence suggests that the presence of fibrotic lesions significantly increases the risk of cancer in numerous tissues, including the lungs, liver and breast [8-11]. Idiopathic pulmonary fibrosis (IPF), which is a progressive and fatal lung disease of unknown etiology, is associated with a higher incidence of lung cancers as compared with the general population [12]. IPF is characterized by scar tissue accumulation in the lung interstitium. The injury to type II alveolar epithelial cells triggers production of TGF- $\beta$ that leads to mitogenesis of macrophages, platelets and myofibroblasts in the injured areas, leading to the formation of fibroblastic foci. Fibroblastic foci containing myofibroblasts at the leading edge of lung fibrosis are an indicator of poor prognosis and decreased survival [13].

The secreted protein acidic and rich in cysteine (SPARC) family of proteins regulate ECM assembly and growth factor signaling to modulate interactions between cells and the extracellular environment $[14,15]$. SPARC (also known as osteonectin, an acidic extracellular matrix glycoprotein) binds to soluble procollagen and prevents procollagen from interacting with cellular receptors, such as discoidin domain receptor 2 and integrins $[15,16]$. In the absence of SPARC, procollagen accumulates at the cell surface and is inefficiently incorporated into the ECM, resulting in the production of thin collagen fibers. SPARC is thus required for procollagen to be dissociated from the cell surface and incorporated into the ECM.

SPARC is exclusively expressed in IPF patients, never in healthy individuals $[9,17]$. SPARC expression is also tightly correlated with increased collagen deposition. Inhibition of SPARC expression significantly attenuates fibrosis in various animal models of disease [15]. SPARC is also localized in the cytoplasm of the actively-migrating myofibroblasts within the fibroblastic foci [17]. SPARC expression and TGF- $\beta$ signaling are reciprocally regulated; TGF- $\beta$ induces SPARC expression via canonical Smad2/3 signaling in lung fibroblasts and SPARC which, in turn, activates TGF- $\beta$ signaling [18]. TGF- $\beta$ also induces plasminogen activator inhibitor-1 (PAI-1) expression via Smad2/3 signaling in lung fibroblasts. Moreover, SPARC-activated integrin promotes Akt activation that inhibits glycogen synthase kinase-3 $\beta$ (GSK-3 $\beta$ ) by serine-9/21 phosphorylation, leading to $\beta$-catenin activation and PAI-1 expression [17]. As PAI-1 prevents lung fibroblasts from undergoing apoptosis induced by plasminogen, ectopic SPARC expression in IPF apparently mediates the progression of interstitial fibrosis by inhibiting apoptosis in lung myofibroblasts via $\beta$-catenin activation and PAI- 1 expression in collaboration with the TGF- $\beta$ signal pathway. Taken together, the observations of these cellular mechanisms by which SPARC promotes the activation of fibroblasts in culture and its fibrosis-promoting ability in vivo encourage investigators to seek therapeutic strategies for blocking SPARC activity. Such research may lead to the eradication of fibrotic diseases.

In contrast to the fibrosis-promoting SPARC function, the roles of stromal SPARC in human carcinomas appear to be far more complex and even contradictory according to previous reports. Enhanced SPARC expression in the tumor-associated stroma correlates with a poor prognosis for patients with non-small cell lung cancers (NSCLC) [19] and pancreatic adenocarcinomas [20], but not for those with bladder cancers [21]. Chemical agent-induced bladder carcinomas have been shown to grow and progress more significantly in SPARC ${ }^{-/-}$mice than in control SPARC ${ }^{+/+}$mice [21]. Murine carcinoma-associated fibroblasts (CAFs) extracted from SPARC ${ }^{-/-}$bladder carcinomas also exhibit enhanced inflammatory phenotypes via NF- $\mathrm{KB}$ and AP-1 signaling, thereby promoting tumor growth and metastasis, indicating a tumor-suppressive role of SPARC in bladder CAFs. Collectively, these observations indicate cell-context dependent roles of stromal SPARC in different tumors.

Furthermore, non-alcoholic steatohepatitis (NASH), characterized by fat accumulation, inflammation and liver cell damage, leads to advanced fibrosis and cirrhosis, thereby increasing the risk of developing hepatocellular carcinoma (HCC) [22,23]. Diabetes mellitus (DM) with insulin resistance has also been demonstrated to be an independent risk factor for HCC development in 
NASH patients [23,24]. Activation of insulin-like growth factor 1 (IGF1) signaling stimulates cellular proliferation by activating the mitogen-activated protein kinase (MAPK) pathway and increases the transcription of c-Fos and c-Jun proto-oncogenes [25-27]. Moreover, phosphatase and tensin homologue deleted on chromosome 10 (PTEN) is a crucial negative regulator of the insulin signal pathway mediated by suppression of the phosphatidylinositol-3 kinase (PI3K)-Akt signal pathway. It has been shown that concomitant down-regulation of PTEN and up-regulation of c-Met occurs in HCC, leading to poor clinical outcomes [28]. Loss of PTEN function leads to the accumulation of phosphatidylinositol-3,4,5-triphosphate (PIP3), which mimics the effects of PI3K activation and triggers the activation of its downstream effectors, PDK1, Akt and Rac1/CDC42. Taken together, these observations demonstrate that NASH induces activation of an oncogenic signal transduction series of events in the non-cancerous liver to initiate tumor development.

\subsection{Epithelial-Mesenchymal Transition (EMT) and Endothelial-Mesenchymal Transition (EndoMT) in Fibrosis and Tumor Stroma}

As the saying "tumors: wounds that do not heal" goes, myofibroblasts in wounds and fibrosis mimic CAFs within a tumor $[4,29,30]$ (Figure 1). Epithelial cells frequently transdifferentiate into mesenchymal cells through EMT during wound healing and fibrosis. EndoMT, another form of cellular transition, has also emerged as a mechanism underlying pathological fibrosis development [31-33]. Lineage-tagging experiments using a murine fibrosis model of renal injury indicate that about $30 \%$ of the cells involved are derived from tubular epithelial cells via EMT, while about 35\% arise from EndoMT [34].

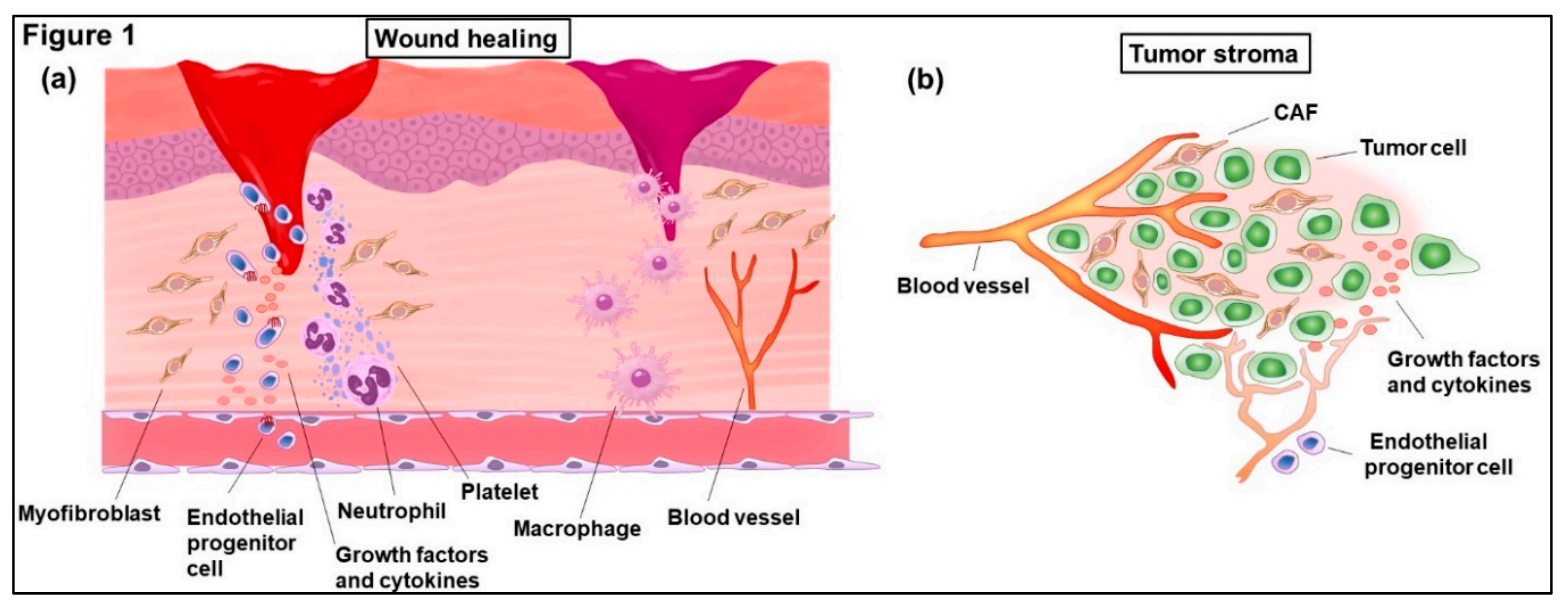

Figure 1. Schematic representation of both wound healing and tumor stroma. Platelets, inflammatory immune cells including neutrophils and macrophages, vascular endothelial cells and activated fibroblasts (myofibroblasts and carcinoma-associated fibroblasts (CAFs)) are recruited into granulation tissues during wound healing (a) and tumor stroma (b).

EndoMT is a complex biological process in which endothelial cells lose their molecular markers, such as vascular endothelial cadherin (VE cadherin), and acquire the myofibroblastic phenotype expressing mesenchymal markers including $\alpha$-SMA, type I collagen, and vimentin. These cells also gain motility and are thus capable of migrating into the surrounding tissues [31]. TGF- $\beta$ treatment induces the downstream signaling pathway to significantly upregulate Snail1 expression in endothelial cells via EndoMT [35-37]. This observation strongly suggests that EMT and EndoMT share the similar molecular mechanisms. Remarkably, TGF- $\beta 1$-induced EndoMT occurs independently of Smad2/3 phosphorylation via non-canonical TGF- $\beta$ signaling [31]. Furthermore, several important kinases including the c-Abl protein kinase (c-Abl), protein kinase $C \delta(P K C-\delta)$ and GSK-3 $\beta$, have been shown to play pivotal roles in this Smad-independent TGF- $\beta$ pathway. In the absence of GSK- $3 \beta$ phosphorylation, the kinase activity of GSK- $3 \beta$ is promoted and induces proteasomal degradation of 
Snail1, thereby abrogating EndoMT. Both c-Abl and PKC- $\delta$ are required for GSK-3 $\beta$ phosphorylation to induce EndoMT [38]. From the perspective of preventing tissue fibrosis, the inhibition of GSK-3 $\beta$ serine-9 phosphorylation by a specific inhibitor of PKC- $\delta$, i.e., rottlerin, or by c-Abl, widely known as imatinib, degrades Snail1 and thereby inhibits EndoMT [31]. Thus, rottlerin and imatinib both effectively suppress acquisition of the myofibroblastic phenotype and pathological fibrotic changes.

Myofibroblasts reportedly promote the induction and maintenance of EMT of epithelial cells at wound edges $[4,39]$. When this physiological EMT process is disrupted, wounds cannot heal. For instance, wound re-epithelialization of dermal tissue is compromised in mice lacking functional Slug, which is one of the transcription factors involved in TGF- $\beta$-induced EMT $[40,41]$. To achieve EMT at the wound edge, myofibroblasts secrete extracellular proteolytic enzymes, such as MMPs, which cleave ECM components and release potent TGF- $\beta$ (latent form) and other EMT-inducing cytokines [6,42]. This is an intriguing parallel with the role EMT in cancer development and progression; while cancer cells are regulated by cytokines, such as TGF- $\beta$, these cytokines become tethered within the ECM, such that it remains ready for mobilization in response to certain triggers.

Stromal myofibroblasts are also observed in proximity to carcinoma cells associated with the EMT phenotype [43]. CAFs in this context participate in the release and bioavailability by secreting extracellular proteases and ECM-remodeling enzymes. It was previously shown that normal colonic fibroblasts differentiate into $\alpha$-SMA-positive CAFs and secrete larger amounts of MMP2 and urokinase-type plasminogen activator (uPA) associated with various cancer cells $[44,45]$. These proteolytic enzymes have been suggested to cleave various ECM components such as decorin, which covalently and potently binds to TGF- $\beta$ and prevents the potential ligand from binding to the TGF- $\beta$ receptor in adjacent cancer cells [46]. ECM components act as a reservoir for various cytokines; since decorin is able to bind TGF- $\beta 1$, proteolytic degradation of decorin results in the release of this sequestered TGF- $\beta$ ligand [47]. These lines of evidence all strongly suggest that paracrine signaling from CAFs and myofibroblasts in a wound regulates epithelial-mesenchymal plasticity in nearby epithelial cells to further promote tumor progression and fibrosis, respectively.

\section{Fibrosis-Induced Tumor Progression}

\subsection{Origin and Differentiation into CAFs}

Although CAFs represent a major cellular component of the tumor stroma, a precise molecular definition of CAFs is as yet lacking. Attempts to define CAFs are usually aimed at identifying morphological features and expression patterns of the following proteins: $\alpha$-SMA, asporin, collagen 11- $\alpha 1$ (COL11A1), fibroblast-activating protein (FAP), platelet-derived growth factor receptor (PDGFR) $\alpha / \beta$, fibroblast-specific protein 1 (FSP1, also called S100A4), podoplanin, SPARC, S100A4, tenascin-C, microfibrillar-associated protein 5 (MFAP5), and vimentin [33,48-50]. However, none of these markers are specific to CAFs. Lack of the appropriate molecular markers for identifying tumor-promoting CAFs thus makes it difficult to elucidate the biology of these fibroblasts. Such a precise understanding would be the first, and most fundamental, step toward developing a cell type-specific targeting approach.

CAFs produce growth factors and inflammatory cytokines that are capable not only of regulating fibroblast activation in an autocrine fashion, but also of controlling the behaviors of cancer cells as well as other stromal cells, along with remodeling the ECM in a paracrine manner [33,51,52]. CAFs transdifferentiate from their progenitors, such as resident fibroblasts, endothelial cells, preadipocytes and bone marrow-derived mesenchymal stem cells (MSCs) during tumor progression [50,53-55]. MSCs are known to differentiate into CAFs in culture [56]. Injection of MSCs with carcinoma cells into immunodeficient mice also results in enhanced tumor growth and metastasis presumably through differentiation into tumor-promoting CAFs [57]. However, how differences among cells of origin for CAFs impact their biological functions has yet to be elucidated. A recent elegant study demonstrated the unique roles of CAFs originating from bone marrow in breast carcinomas [58]. Using MMTV-PyMT transgenic mice and adaptive bone marrow transplantation techniques, Raz et al. showed bone 
marrow-derived CAFs extracted from breast tumors to have proangiogenic traits and that, when implanted into recipient mice, these traits were significantly more marked than in those locally arising from the mammary gland. They also found decreased PDGFR $\alpha$ expression to allow bone marrow-derived CAFs to be distinguished from other CAF populations in breast tumors, highlighting distinct fibroblast populations present in the tumor.

Myofibroblastic CAFs are induced de novo from their progenitors including normal fibroblasts, when treated with TGF- $\beta$, platelet-derived growth factor (PDGF), Wnt7a, exosomes and microRNAs in culture [49,50,59-61]. Activation of fibroblasts with a pro-inflammatory state also occurs in otherwise non-activated fibroblasts treated with interleukin (IL)-1 $\beta$, IL-6, leukemia inhibitory factor (LIF) and osteopontin $[62,63]$. However, it remains unknown whether these de novo generated CAFs continue to maintain their activated, tumor-promoting traits after a series of passages in culture or incubation with carcinoma cells within a tumor mass.

From the perspective of epigenetic modifications in myofibroblasts, LIF induces constitutive activation of the Janus kinase 1 (JAK1)/STAT3 signaling pathway mediated by post-translational regulation of STAT3 acetylation by p300 [64-66]. The acetylated STAT3 causes an epigenetic-dependent loss of expression of the Src homology region 2 domain-containing phosphatase-1 (SHP-1) tyrosine phosphatase, which is a negative regulator of the JAK/STAT pathway $[67,68]$. Silencing of SHP-1 gene expression by promoter methylation leads to sustained phosphorylation of JAK1 kinase and the STAT3 transcription factor that maintain the contractile and invasive abilities of CAFs [65]. Blockage of both JAK signal and DNA methyltransferase activities results, both in vitro and in vivo, in the reversal of the invasive phenotype of CAFs.

Table 1 shows the common activated signal pathways in both wound-induced activated fibroblasts and CAFs. This table comparatively details the biological roles of growth factors and cytokines in wound-healing and tumor stroma settings.

Table 1. The critical signal pathways activated in both wound-induced fibroblasts and CAFs.

\begin{tabular}{|c|c|c|}
\hline Signal Pathway & Wound-Induced Fibroblasts & CAFs \\
\hline Epithelial growth factor (EGF) & $\begin{array}{l}\text { EGF stimulation increases the } \\
\text { phosphorylation of myosin light } \\
\text { chain (MLC) subunit of myosin } \\
\text { that promotes cell contractility in } \\
\text { various different cell types. } \\
\text { Activation of PKC with the PKC- } \delta \\
\text { isoform mediates the cell } \\
\text { contraction by EGF-stimulated } \\
\text { MLC phosphorylation in murine } \\
\text { fibroblast cells [69]. }\end{array}$ & $\begin{array}{l}\text { Resistance to the epidermal } \\
\text { growth factor receptor (EGFR) } \\
\text { tyrosine kinase inhibitor (TKI) is } \\
\text { partially medicated by CAFs in } \\
\text { tumors through paracrine factors } \\
\text { secreted from these fibroblasts } \\
\text { [70]. }\end{array}$ \\
\hline Fibroblast growth factor (FGF) & $\begin{array}{l}\text { FGFs have the biological activity } \\
\text { of stimulating the proliferation of } \\
\text { fibroblasts and angiogenesis [71]. } \\
\text { FGFs exert multiple functions } \\
\text { through binding to and activation } \\
\text { of fibroblast growth factor } \\
\text { receptors (FGFRs), and the main } \\
\text { signaling through the stimulation } \\
\text { of FGFRs is the RAS/MAPK signal } \\
\text { pathway. }\end{array}$ & $\begin{array}{l}\text { CAFs secrete increased levels of } \\
\text { FGF-1/-3 and promote cancer cell } \\
\text { growth and angiogenesis through } \\
\text { the activation of FGFR4, which is } \\
\text { followed by the activation of } \\
\text { extracellular signal-regulated } \\
\text { kinase (ERK) and the modulation } \\
\text { of MMP-7 expression [72]. In } \\
\text { addition, FGF-1 and FGF-3 act as } \\
\text { primary autocrine mediators of } \\
\text { epithelial-stromal interactions in } \\
\text { the tumor progression. }\end{array}$ \\
\hline
\end{tabular}


Table 1. Cont.

\begin{tabular}{|c|c|c|}
\hline Signal Pathway & Wound-Induced Fibroblasts & CAFs \\
\hline JAK/STAT & $\begin{array}{l}\text { Synovial fibroblasts mediate } \\
\text { chronic inflammation and joint } \\
\text { destruction in patients suffered } \\
\text { from rheumatoid arthritis (RA). } \\
\text { Increased levels of IL-6, TNF- } \alpha \\
\text { and IL-1 } \beta \text { production activate } \\
\text { STAT3 signaling that in turn } \\
\text { boosts expression levels of these } \\
\text { cytokines in an autocrine fashion } \\
\text { in synovial fibroblasts, promoting } \\
\text { chronic inflammation [73]. STAT3 } \\
\text { activation also induces receptor } \\
\text { activator of nuclear factor kappa B } \\
\text { ligand (RANKL) expression that } \\
\text { stimulates osteoclastogenesis and } \\
\text { thus promotes the joint } \\
\text { destruction [73]. }\end{array}$ & $\begin{array}{l}\text { CAFs release high levels of IL-6 } \\
\text { and CCL2 upon STAT3 activation } \\
\text { in co-culture system with cancer } \\
\text { cells, promoting the self-renewal } \\
\text { and spheroid forming potentials of } \\
\text { cancer stem cells [74]. } \\
\text { Furthermore, the leukemia } \\
\text { inhibitory factor (LIF)-induced } \\
\text { JAK1/STAT3 signaling pathway } \\
\text { mediates expression of the } \\
\text { invasive CAF phenotype [75]. }\end{array}$ \\
\hline PDGF & $\begin{array}{l}\text { PDGFs induce fibroblast activation } \\
\text { and fibrosis. PDGF-BB stimulates } \\
\text { polarization and provides } \\
\text { enhancement and directionality } \\
\text { for collagen-driven human dermal } \\
\text { fibroblast migration. Akt } \\
\text { processes both migratory and } \\
\text { proliferative signals from PDGF } \\
\text { receptors [76]. }\end{array}$ & $\begin{array}{l}\text { Breast tumor cells produce } \\
\text { PDGF-CC to activate stromal } \\
\text { fibroblasts that in turn confer the } \\
\text { basal and estrogen receptor } \alpha- \\
\text { negative phenotypes into cancer } \\
\text { cells, rendering them } \\
\text { unresponsive to endocrine } \\
\text { treatment [77]. }\end{array}$ \\
\hline $\mathrm{PGE}_{2}$-Wnt & $\begin{array}{l}\text { Dermal fibroblasts expressing a } \\
\text { low level of Dickkopf } 1 \text {, a Wnt } \\
\text { signaling antagonist, exhibit } \\
\text { enhancement of the canonical } \\
\text { Wnt/ } \beta \text {-catenin signal pathway } \\
\text { with accumulation of } \\
\text { prostaglandin } \mathrm{E}_{2}\left(\mathrm{PGE}_{2}\right)[78] \text {. The } \\
\text { PGE }_{2} \text { signaling also increases } \\
\text { nuclear } \beta \text {-catenin signaling in } \\
\text { fibroblasts. }\end{array}$ & $\begin{array}{l}\text { Autocrine activity of } \mathrm{PGE}_{2} \\
\text { regulates the production of } \\
\text { angiogenic factors by fibroblasts, } \\
\text { which are key to the } \\
\text { vascularization of both primary } \\
\text { and metastatic tumor growth [79]. } \\
\text { Simultaneous activation of } \text { PGE }_{2} \\
\text { and Wnt signals in transgenic mice } \\
\text { causes gastric cancer with an } \\
\text { abundance of vascular endothelial } \\
\text { growth factor-A (VEGF-A) } \\
\text { expressing CAFs, derived from } \\
\text { bone marrow [80]. }\end{array}$ \\
\hline TGF- $\beta$ & $\begin{array}{l}\text { Upon TGF- } \beta \text { stimulation, } \\
\text { fibroblasts are activated and } \\
\text { undergo phenotypic transition } \\
\text { into myofibroblasts, the key } \\
\text { effector cells under fibrotic } \\
\text { conditions. The myofibroblast } \\
\text { phenotype is characterized by the } \\
\text { formation of gap junctions and by } \\
\text { the acquisition of a contractile } \\
\text { apparatus with associated } \\
\text { contractile proteins. In healing } \\
\text { wounds, myofibroblasts are } \\
\text { required for tissue repair prior to } \\
\text { their elimination due to the } \\
\text { induction of apoptosis, but } \\
\text { constitutively activated } \\
\text { myofibroblasts promote fibrosis } \\
\text { [81]. }\end{array}$ & $\begin{array}{l}\text { Increased TGF- } \beta \text { production by } \\
\text { tumor cells gives rise to the } \\
\text { desmoplastic stroma in murine } \\
\text { tumor models }[82,83] \text {. TGF- } \beta \\
\text { potently suppresses immunity, } \\
\text { induces angiogenesis and } \\
\text { promotes cancer cell migration } \\
\text { and invasion by stimulating EMT. } \\
\text { Moreover, cancer cell-derived } \\
\text { TGF- } \beta \text { activates TGF- } \beta \text { signaling } \\
\text { in CAFs, inducing the } \\
\text { up-regulation of monocarboxylate } \\
\text { transporter } 4 \text { (MCT4) (a marker of } \\
\text { glycolysis) and BNIP3 (a marker of } \\
\text { autophagy) and the loss of } \\
\text { caveolin-1 (CAV1) [84]. }\end{array}$ \\
\hline
\end{tabular}




\subsection{Emerging Roles of CAFs for Therapeutic Resistance}

Recent emerging evidence supports crucial roles of CAFs for therapeutic resistance, as exemplified by innate and adaptive resistance in various human carcinomas (Figure 2).

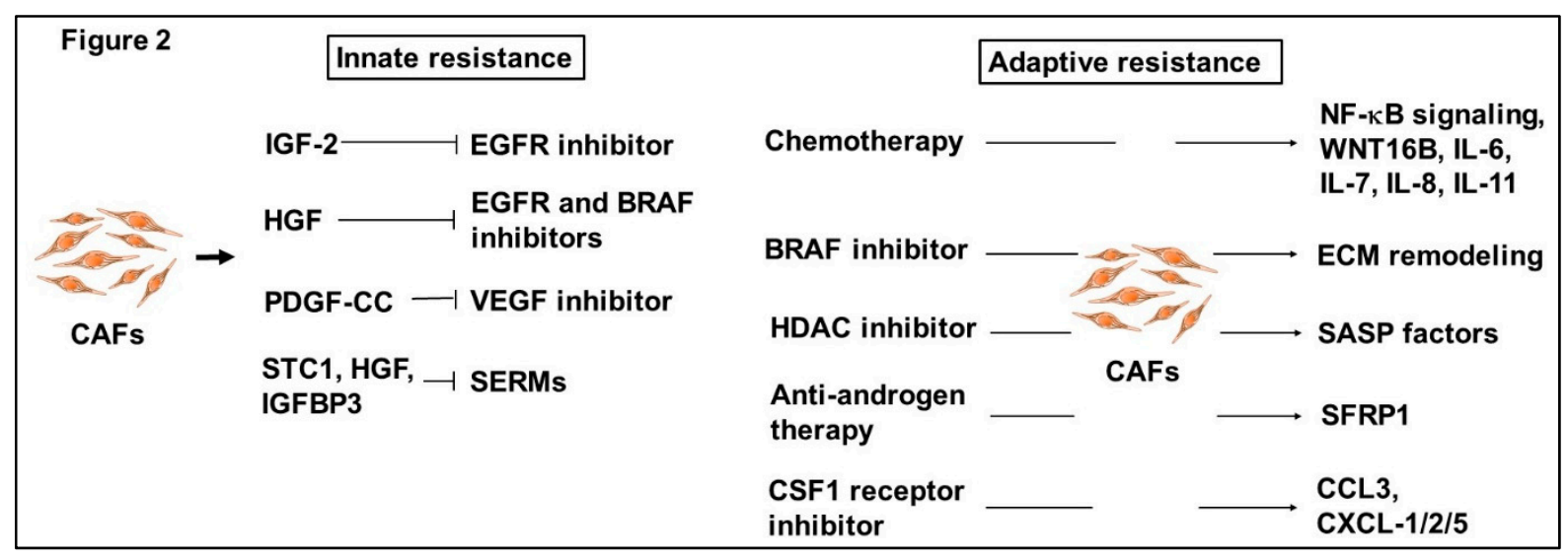

Figure 2. Emerging roles of CAFs for therapeutic resistance. CAFs play crucial roles in innate resistance to anti-cancer drugs (left). CAF-released insulin-like growth factor 2 (IGF2) provides cancer cells with tumor-initiating ability and EGFR-TKI-resistance. HGF produced by CAFs blunts the efficacy of BRAF and EGFR inhibitors in BRAF-mutant melanoma cells and lung cancer cells via MAPK and PI3K/AKT signal pathways. CAF-produced PDGF-CC attenuates the efficacy of anti-VEGF therapy via increasing neo-angiogenesis. Breast tumor cell-derived PDGF-CC also enables CAFs to produce stanniocalcin 1 (STC1), HGF and IGFBP3 that contribute to promoting conversion of luminal cancer cells into basal cancer cells, resulting in resistance to treatment with selective estrogen receptor modulators (SERMs). Upon therapeutic insult, CAFs acquire adaptive resistance (right). Chemotherapy induces pro-inflammatory phenotypes in CAFs via activation of NF-kB signaling, resulting in enhanced production of Wnt family member wingless-type MMTV integration site family member 16B (WNT16B), IL-6 and IL-8 from these fibroblasts that provides breast cancer cells with chemoresistant ability. Increased levels of IL-7 and IL-11 production are also induced in CAFs by chemotherapy, rendering cancer cells tumor-initiating and apoptosis-resistant. Treatment of CAFs with the BRAF inhibitor induces ECM remodeling, resulting in activation of integrin $\beta 1 /$ focal adhesion kinase (FAK)/Src and ERK signaling in melanoma cells. The histone deacetylase (HDAC) inhibitor treatment enables CAFs to produce the senescence-associated secretory phenotype (SASP) factors. Exposure to anti-androgen therapy encourages CAFs to produce SFRP1 that promotes prostate cancer neuroendocrine differentiation. Treatment of different human carcinomas with the CSF1 receptor inhibitor targeting TAMs allows CAFs to boost CCL3 and CXCL-1/2/5 productions, resulting in the recruitment of MDSCs into tumors and thus promoting tumor growth and progression.

\subsubsection{Innate Resistance of CAFs to Anti-Cancer Drugs}

CAFs produce inherently increased levels of growth factors and inflammatory cytokines that attenuate the efficacy of anti-cancer treatment. For example, CAFs produce an abundance of insulin-like growth factor 2 (IGF2) that renders cholangiocarcinoma and pancreatic cancer cells resistant to EGFR tyrosine kinase inhibitors (TKI) by activating the insulin receptor (IR)/insulin-like growth factor 1 receptor (IGF1R) signaling axis $[85,86]$. CAF-produced IGF2 also reportedly promotes invasion and metastasis of colon cancer cells [87]. Moreover, stromal IGF2 induces NANOG expression and thus boosts the cancer-initiating properties of lung cancer cells through IR/IGF1R signaling followed by activation of the AKT-PI3K pathway [88].

Mechanisms underlying the stroma-mediated innate resistance to the BRAF inhibitor have also been addressed using BRAF-mutant melanoma cells in other studies. Hepatocyte growth factor (HGF) released from fibroblasts contributes to resistance to the BRAF inhibitor, presumably via the downstream signaling of the MAPK and PI3K/AKT pathways [89]. While treatment with BRAF- 
and MEK-inhibitors is not sufficient to overcome HGF-induced resistance, BRAF- and MET (the HGF receptor)-inhibitors suppress the majority of HGF-induced drug resistance in BRAF-mutant melanoma [89,90]. Similarly, HGF-producing human fibroblastic cells confer resistance to gefitinib, a TKI selective to EGFR in lung cancer cells through the PI3K/Akt signal pathway [91]. Importantly, anti-HGF neutralizing antibody and the natural HGF inhibitor NK4 significantly overcome the gefitinib resistance in culture and in tumor xenografts raised by lung cancer cells admixed with HGF-producing human fibroblasts in mice treated with gefitinib.

Inhibition of VEGF-A is effective in treating several human carcinomas [92]. However, tumors often show resistance to anti-VEGF treatment. Importantly, CAFs have been shown to mediate the resistance to anti-VEGF therapy and the molecular mechanism was elucidated in murine lymphoma models [93]. Murine CAFs were isolated from subcutaneous tumors developed by lymphoma cell lines resistant to the antiangiogenic therapy with VEGF inhibitors. The increased level of PDGF-CC produced by CAFs resulted in rendering tumor cells resistant to anti-VEGF therapy by stimulation of neoangiogenesis, when lymphoma cells otherwise sensitive to anti-VEGF therapy were co-implanted with these fibroblasts into recipient mice [93].

Human breast cancers of the luminal subtypes expressing female hormone receptors are effectively treated with selective estrogen receptor modulators (SERMs), such as tamoxifen, while tumors of the basal-like subtype that do not express hormone receptors fail to have effective targeted therapies. Roswall et al. have recently demonstrated that CAFs play crucial roles in regulating the phenotypic conversion of luminal breast cancers into basal-like cancers, which show the worst overall survival among various human breast cancer subtypes [77]. Human breast cancer cells produce PDGF-CC that acts onto the cognate PDGF receptors expressed on closely apposed CAFs to activate these fibroblasts. The resulting activated CAFs produce stanniocalcin 1 (STC1), HGF and insulin growth factor binding protein 3 (IGFBP3), all of which downregulate the expression levels of the luminal markers including FOXA1, estrogen receptor and GATA3, resulting in the conversion of the luminal tumors into basal-like tumors [77]. Notably, the luminal phenotype and sensitivity to endocrine therapy were shown to be restored in otherwise resistant tumors, not only by genetic targeting of the PDGF-C gene in the MMTV-PyMT murine basal-like breast cancer model, but also by treatment with the neutralizing PDGF-CC antibody of patient-derived triple-negative breast tumor xenografts transplanted orthotopically in immunodeficient mice.

\subsubsection{Adaptive Resistance of CAFs to Anti-Cancer Drugs}

CAFs have been shown to prime chronic inflammation, as exemplified by recruitment of protumorigenic macrophages in an NFKB signal-dependent fashion, resulting in the promotion of tumor growth and angiogenesis [94]. With stress exposures, such as chemotherapy and radiation, these fibroblasts also acquire the pro-inflammatory phenotype via further activating NFKB signaling, resulting in increased survival signals of cancer cells. The activated NFKB signaling in the therapy-treated CAFs enhances production of different cytokines including Wnt family member wingless-type MMTV integration site family member 16B (WNT16B), IL-6 and IL-8, leading to the induction of chemoresistance in breast cancer cells $[95,96]$. CAFs treated with cisplatin also boost IL-11 production to activate the STAT3 signal pathway and upregulate the expressions of the anti-apoptotic proteins such as Bcl-2 and survivin for prostate cancer cells to acquire resistance to apoptosis [97]. Moreover, CAFs extracted from freshly resected human colorectal cancer specimens after chemotherapy reportedly show higher IL-7 production than those without chemotherapy [98]. This stromal IL-7 provides CD44-positive colon cancer cells with further increased tumor-initiating ability, thereby promoting tumor cell growth both in vitro and in vivo [98].

Furthermore, chemotherapy-induced stromal chronic inflammation is responsible for angiogenesis and ECM remodeling, and subsequently provides tumor cells with a physical barrier against the cytotoxic agents administered $[33,99,100]$. Recent investigations have shown that conventional chemotherapy and radiotherapy can lead to increased tumor stiffness involving the stroma response [49,101,102]. 
Remarkably, treatment with PLX-4270 (BRAF inhibitor) activates tumor-associated fibroblasts to induce ECM remodeling that activates integrin $\beta 1 / F A K / S r c$ signaling in melanoma cells [101]. This signal activation then renders melanoma cells resistant to PLX-4270 via ERK activation.

Treatment of stromal fibroblasts with high concentrations of HDAC inhibitors, such as SAHA, TSA and vorinostat, causes the senescence-associated secretory phenotype (SASP) mediated by the direct activation of the NFKB signal $[103,104]$. Treating fibroblasts with HDAC inhibitors results in significant paracrine stimulation of tumor growth, which suggests that high-dose HDAC inhibitors would likely impact the stromal compartment adversely in a therapeutic setting.

Intriguingly, androgen deprivation therapy increases the population of CD105 (endoglin)-positive CAFs, which contribute to neuroendocrine differentiation of epithelial prostate carcinoma cells [105]. CAF-derived secreted frizzled-related protein 1 (SFRP1), which is driven by the CD105-mediated signal pathway, is both necessary and sufficient to induce the neuroendocrine differentiation of prostate carcinoma in a paracrine manner. These series of observations raise concern regarding the undesirable side effects of therapeutic agents; paracrine signaling from treatment-primed CAFs might influence the regrowth and malignancy of nearby tumor cells.

CAFs play a key role in driving the drug resistance not only by raising particular gene expression patterns and signaling pathways as mentioned above, but also by stimulating recruitment of immunosuppressive cells into the tumor. Tumor-associated macrophages (TAMs) are non-neoplastic cells abundant in stroma of different human tumors and exert either pro-tumoral or tumoricidal functions in response to cytokine exposure [106,107]. A growing body of evidence indicates that pro-tumoral TAMs support tumor growth and progression by influencing tumor hallmarks [107]. Colony-stimulating factor 1 (CSF1) receptor signaling is a key regulator of TAM recruitment, differentiation and survival. Treatment with CSF1 receptor inhibitors targeting TAMs clearly reduces tumor growth in murine tumor models, though the anti-tumor effect was shown to be very limited in patients [106]. The molecular mechanisms underlying the tumor progression elicited by substantial depletion of TAMs remain, however, unknown. Importantly, a recent study revealed this to be due to increased CCL3 and CXCL-1/2/5 productions from CAFs treated with the CSF1 receptor inhibitor [108]. These CAF-produced chemokines then stimulate the recruitment of polymorpho-nuclear myeloid-derived suppressor cells (PMN-MDSCs) into tumors, resulting in the promotion of tumor growth and progression. These findings therefore demonstrate that CAFs mediate neutralization of the anti-tumor effect exerted by CSF1 receptor inhibitors via recruitment of PMN-MDSCs into tumors.

\subsection{Cross-Talk between CAFs and Tumor Microenvironment}

The wound-healing program is strongly dependent on the cross-talk between various stromal cells and myofibroblasts at the wound site $[109,110]$ (Figure 1). For instance, myofibroblasts induce angiogenesis from preexisting parental vessels or from the circulating endothelial precursor cells (EPCs) recruited at the wound site via the secretion of a potent preangiogenic chemokine, CXCL12, also known as stromal cell-derived factor-1 (SDF-1) [111,112]. Chemotactically-attracted EPCs then transdifferentiate into endothelial cells in the presence of VEGF, which is also secreted by myofibroblasts.

In certain contexts, myofibroblastic CAFs induce neo-angiogenesis via secretion of preangiogenic factors including CXCL12, VEGF, PDGF, TGF- $\beta$ and HGF in a wide range of cancers $[49,50,113-117]$. Most desmoplastic tumors are highly vascularized, wherein shifting the switch toward an angiogenesis-promoting phenotype occurs $[118,119]$. Interestingly, as in the case of wound healing, the CAF niches depend on the CXCL12/CXCR4 axis and VEGF production to stimulate the formation of neovasculature at the invasive front of breast cancer [115,120-122]. As the CXCR4 receptor for CXCL12 is expressed on both the tumor cells and EPCs [123,124], CAF-produced CXCL12 stimulates tumor growth and neoangiogenesis via acting CXCR4 expressed on these cells. The production of VEGF from tumor cells and CAFs also boosts neoangiogenesis in breast cancer tissues. Collectively, niches of myofibroblasts in wounds and CAFs are both likely to support angiogenesis, apparently through similar signaling pathways. 
It was recently shown that hypermethylated in cancer 1 (HIC1), which is a tumor suppressor gene located at 17p13.3, resides exclusively within $\mathrm{CpG}$ islands, frequently showing hypermethylation in several tumors such as breast, lung and prostate carcinomas [125-128]. A recent study found that HIC1-depleted breast cancer cells markedly produce CXCL14 that activates Akt and ERK1/2 signal pathways, by acting through its cognate receptor GPR85 on resident fibroblasts in a paracrine manner, resulting in the induction of a phenotypic conversion into CAFs [127]. The activated CAFs, in turn, boost the production of chemokine CCL17 that acts on its cognate receptor CCR4, located on breast cancer cells, to drive metastasis. Collectively, the HIC1-CXCL14-CCL17 positive-feedback loop reciprocally mediating interactions between breast tumor cells and myofibroblastic CAFs contributes to the malignant potentials of breast tumors.

CAFs remodel the ECM components and thereby regulate tumor stiffness [129]. It was recently shown that squamous cancer cells activate EGFR in response to tumor stiffness, which leads to actomyosin contractility and collective invasion [130]. From a mechanistic standpoint, enhanced tyrosine kinase activity of EGFR results in $\mathrm{Ca}^{2+}$-dependent regulation of Cdc42 small GTPase activity in tumor cells, which in turn leads to phosphorylation of MLC2. The MLC kinase regulates actomyosin-dependent ECM remodeling due to CAFs. Surprisingly, two $\mathrm{Ca}^{2+}$ channel blockers, the phenylalkylamine verapamil and the nondihydropiridine diltiazem, which have been used for treating hypertension and arrhythmia for decades, show the therapeutic efficacy for preventing collective cancer invasion, an effect achieved by significantly down-regulating the phosphorylation of MLC2.

It is noteworthy that mechanical force-mediated ECM remodeling by CAFs depends on actomyosin contractility generated through the Rho-associated protein kinase (ROCK) signal pathway [129]. The IL-6/JAK1/signal transducer and activator of transcription 3 (STAT3) axis also controls actomyosin contractility by regulating the levels of phosphorylated-MLC2 in both melanoma cells and CAFs. In striking contrast to melanoma cells, in which the IL-6-gp130/ JAK1-ROCK axis is required for the amoeboid-like individual tumor migration, this signaling pathway is not required for the migration of squamous carcinoma cells themselves, but is required for CAFs to remodel the matrix, which is necessary for promoting the collective invasion of these carcinoma cells [64].

EMT of epithelial tumor cells, the process by which the number of tumor-initiating cells (TICs) is increased [131,132], is apparently regulated in cooperation with CAFs. Recent studies also highlight the importance of epithelial-mesenchymal plasticity to be determined by several transcription factors, including ZEB1, Snail and Twist. The resulting tumor cells with the hybrid epithelial/mesenchymal trait mediated by partial EMT are considered to enhance the tumor-initiating, invasive and metastatic properties as well, along with promoting chemoresistance [132-135]. These phenotypic changes are also presumably induced by CAF-regulated ECM components, exosomes and soluble factors.

\section{Metabolic Reprogramming of CAFs During Cancer Progression}

\subsection{Metabolic Symbiosis Between Cancer Cells and CAFs}

Features of desmoplastic tumor stroma resemble those of wound healing and involution during gestation. Mammography measures and compares the different types of breast tissue visible on a mammogram, which is an X-ray image of the breasts routinely used to screen for breast cancer in clinics. High breast density represents a greater amount of glandular and connective tissue than fat and has an association with higher risk for breast cancer development [136]. The expression level of CD36, a cell surface receptor for fatty acids, is downregulated in fibroblasts extracted from noncancerous breast tissues with high mammographic density as well as in breast CAFs [137]. CD36 expression is also known to be required for human mammary fibroblasts to transdifferentiate into preadipocytes in culture. Consistently, adipocytes were shown to regenerate from myofibroblasts in a murine skin wound healing model [138]. These findings demonstrate that down-regulation of CD36 expression 
in the stroma results in increased fibrosis in the breast, resulting in high mammographic density, presumably via attenuated transdifferentiation into adipocytes from mammary fibroblasts.

AMP-activated protein kinase (AMPK) reportedly regulates the translocation of the fatty acid transporter CD36 from intracellular stores to the plasma membrane [139], thereby promoting fatty acid uptake into skeletal muscle. CD36 also contributes to the activation of mitochondrial fatty acid $\beta$-oxidation (FAO) which in turn influences their metabolic plasticity in ovarian and oral carcinoma cells, leading to greater lymph node metastasis [140,141].

CD36 is involved in caveolae, a subset of lipid rafts forming part of the cell membrane microdomain enriched in cholesterol and signaling proteins. Decreased expression of CAV1, another component of caveolae within the tumor microenvironment, is also consistently associated with poor clinical outcomes in patients with a wide variety of malignancies [142]. CAV1-deficient fibroblasts also show concomitantly decreased CD36 expression, stabilization of hypoxia-induced factor- $1 \alpha$ (HIF- $1 \alpha)$, activation of TGF- $\beta$ signal transduction and induction of myofibroblast differentiation $[142,143]$. These CD36-deficient fibroblasts likewise undergo a metabolic shift from mitochondrial oxidative phosphorylation to aerobic glycolysis, promoting the metabolic plasticity of these fibroblasts $[142,144,145]$ (Figure 3). These findings suggest that altered caveolae function in the tumor microenvironment induces tumor metabolic heterogeneity, leading to the manifestation of malignant features. These mechanistic insights into how the alteration of caveolae is induced and maintained in CAFs are currently under investigation.

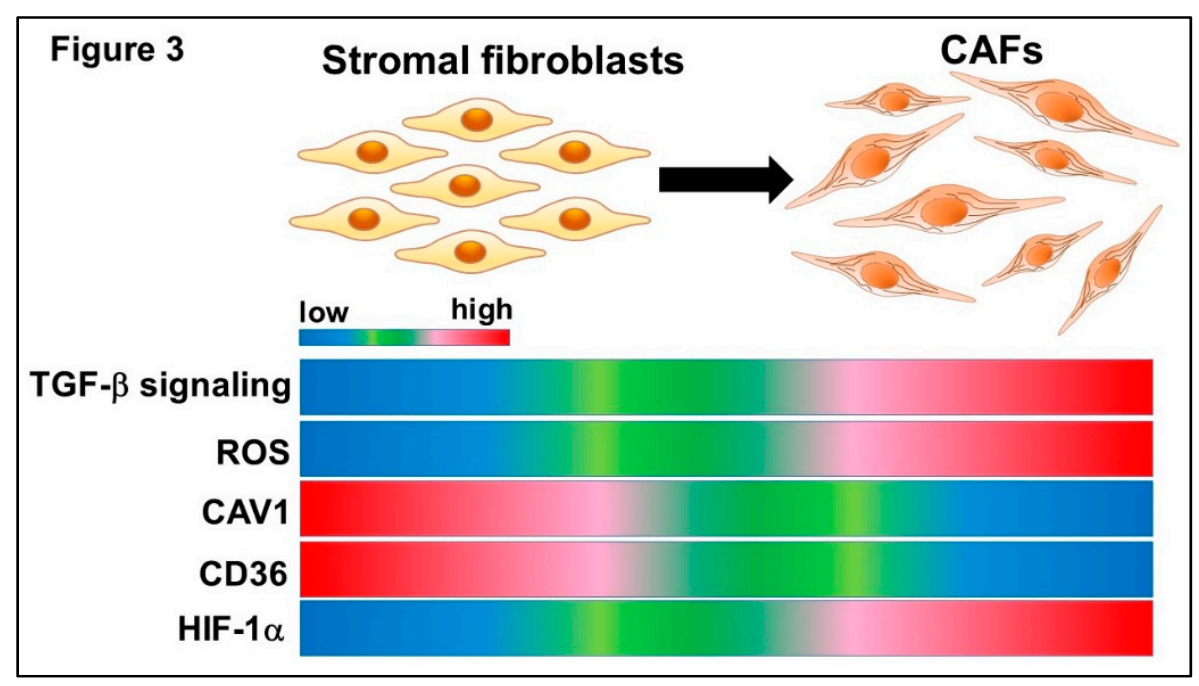

Figure 3. Metabolic reprogramming in CAFs. CD36 and caveolin 1 (CAV1) are components of caveolae, a subset of lipid rafts found in the cell membrane microdomain enriched for cholesterol and signaling proteins. These CD36 and CAV1 expressions are downregulated in CAFs. The attenuated CAV1 expression concomitantly decreases CD36 expression, stabilizes hypoxia-induced factor- $1 \alpha$ (HIF- $1 \alpha)$, activates TGF- $\beta$ signal transduction and induces myofibroblast differentiation in fibroblasts. This attenuated CD36 expression also shows a metabolic shift from mitochondrial oxidative phosphorylation to aerobic glycolysis, promoting metabolic plasticity in these fibroblasts. Tumor-derived reactive oxygen species (ROS) are responsible for down-regulation of CAV1 in CAFs. Loss of CAV1 in CAFs also results in ROS elevations, which in turn stabilize HIF- $1 \alpha$.

Initially, the Warburg effect was believed to be confined to specific tumor cell types [146-148]. However, the emerging concept of a "reverse Warburg effect" has recently attracted considerable research attention $[145,149,150]$. Tumor-derived reactive oxygen species (ROS) are responsible for down-regulation of CAV1 in CAFs [151-153] (Figure 3). Loss of CAV1 in CAFs also results in ROS elevations, which in turn stabilize HIF- $1 \alpha$. In other words, malignant cells induce a "pseudo-hypoxic" microenvironment for CAFs $[145,154]$. Because the transcription factor HIF- $1 \alpha$ promotes glycolysis 
and provides cancer cells with lactate and glutamate, elevated ROS production in tumor cells indirectly induces the uptake of intermediate metabolites of the tricarboxylic acid (TCA) cycle in mitochondria (Figure 4). Of note, CAFs consume more glucose and secrete more lactate than normal fibroblasts [154-156]. Furthermore, CAFs depend significantly on autophagy that may lead to resistance to chemotherapy $[145,155,157]$. Collectively, fibroblasts surrounding epithelial tumor cells undergo metabolic reprogramming, which results in a metabolic phenotype resembling that induced by the Warburg effect. Importantly, metabolic symbiosis between epithelial cancer cells and CAFs requires a cell population to express a different MCT subtype [145,158-161]. Epithelial tumor cells express MCT1, which contributes to uptake of the lactate provided by CAV1-deficient CAFs, which in turn express MCT4, a marker of both aerobic glycolysis and lactate efflux (Figure 4).

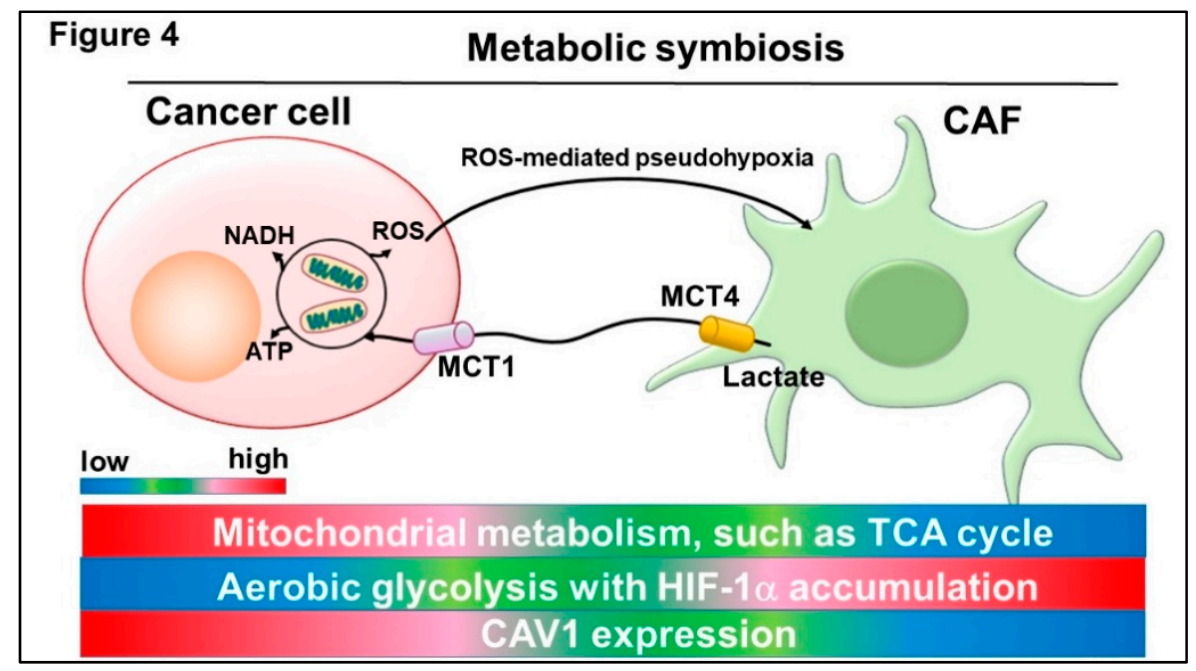

Figure 4. Metabolic symbiosis between cancer cells and CAFs requires the expression of a different MCT subtype. Monocarboxylate transporter 1 (MCT1)-expressing cancer cells induce ROS-mediated pseudohypoxia for MCT4-expressing CAFs, causing HIF- $1 \alpha$ accumulation in the nucleus. CAFs depend on aerobic glycolysis and secrete lactate via MCT4. Cancer cells exhibit robust lactate uptake via MCT1, allowing them to generate large amounts of ATP via the mitochondrial TCA cycle. Tumor cells then efficiently produce metabolic intermediates, such as NADH by utilizing lactate derived from CAFs. ROS are a major hallmark of cancer tissues that drives robust metabolism in adjacent proliferating MCT1-positive cancer cells, which are abundant in mitochondria, mediated by the paracrine transfer of mitochondrial fuels, such as lactate, pyruvate and ketone bodies.

\subsection{Signal Pathways Involved in Metabolic Reprogramming of CAFs}

Accumulating evidence strongly suggests that p62 (also known as sequestosome 1) is involved in metabolic reprogramming of activated fibroblasts in fibrosis and tumor stroma [162-166]. p62 is a multifunctional adaptor protein and a specific substrate for autophagy. p62 is thus selectively incorporated into autophagosomes through the direct binding with LC3 (microtubule-associated protein light chain 3) to be degraded by autophagy $[167,168]$.

Hepatic stellate cells (HSCs), which can transdifferentiate into myofibroblasts in response to certain stimuli, play critical roles in liver fibrosis and HCC development [163]. A study showed that vitamin D receptor (VDR) signaling exerts the anti-fibrotic and anti-inflammatory effects in HSCs [163]. p62 also mediates the anti-fibrotic function by a direct interaction with VDR and the retinoid $\mathrm{X}$ receptor that promotes their heterodimerization, a process critical for target gene recruitment [163]. Moreover, Duran et al. have shown that loss of p62 expression in HSCs enhances their myofibroblastic differentiation, thereby impairing suppression of fibrosis and inflammation by VDR agonists in chemical agent-induced murine fibrosis and tumor models. Consistent with the aforementioned observations, these findings demonstrate decreased p62 expression to be crucial for myofibroblast differentiation to exert their 
actions of supporting fibrosis and tumor growth via attenuated VDR signaling. However, the molecular mechanisms underlying the observed down-regulation of p62 expression in activated fibroblasts remain as yet unknown.

Significant down-regulation of p62 expression also underlies the metabolic reprogramming in CAFs mediated by the mammalian target of rapamycin (mTOR) complex 1/Myc cascade controlling IL-6 secretion [166]. Reduced activity of the mTOR complex 1 in p62-deficient fibroblasts accounts for c-Myc down-regulation and the subsequent up-regulation of IL-6, resulting in the promotion of inflammation and tumorigenesis. The lack of p 62 in CAFs promotes resistance to glutamine deprivation by directly regulating ATF4 stability via its p62-mediated polyubiquitination [162]. Interestingly, selective autophagy mainly regulated by p62 does not account for the capacity of p62-deficient CAFs to withstand glutamine starvation $[162,166]$. Up-regulation of ATF4 due to p62 deficiency in the tumor stroma enhances glucose carbon flux through a pyruvate carboxylase-asparagine synthase cascade, which in turn results in asparagine generation as a compensatory source of the nitrogen required for proliferation of both cancer cells and CAFs. It has been shown both in vitro and in vivo that p62-deficient stromal fibroblasts produce non-essential amino acids which are crucial for proliferation in the absence of glutamine by maintaining the TCA cycle in mitochondria, explaining how the p62-deficient tumor stroma stably provides asparagine in an ATF4-dependent manner [162,164,169]. In addition, CSL/RBPJ $\kappa$, a transcriptional suppressor which is converted into an activator by Notch, plays the role of a negative regulator for CAFs [165]. CSL interacts with p62 and their expression levels are downregulated in murine dermal CAFs through autophagy, indicating that autophagy downmodulates CSL protein expression via p62 in CAFs [165].

\section{Targeting Tumor Stroma Fibroblasts to Attenuate Tumor Progression}

\subsection{Tumor Stiffness and Enhanced Interstitial Fluid Pressure}

As noted above, both tumor cells and CAFs secrete a number of factors which promote angiogenesis, the most widely-accepted of which are members of the VEGF family. Angiogenesis and lymphatic co-options correlate with tumor progression and poor patient outcomes, and are the primary contributors to the altered fluid flow and interstitial fluid pressure (IFP) in the tumor microenvironment [170-172]. Vessels developing in the tumor microenvironment are generally irregular and have major gaps in the endothelial cell layer, reducing the degree of coverage by myofibroblasts and pericytes [173-176]. Furthermore, myofibroblastic CAFs induce not only increases in the numbers of fibrotic foci, but also the contraction of the interstitial space [33,177]. The increased vessel number in conjunction with increased hydraulic conductivity or the relative ease with which fluid moves across the vessel wall, is responsible for the irregular and increased influx of fluid into the tumor stroma. Indeed, rising IFP is frequently reported in solid tumors, such as breast carcinoma, glioblastoma and malignant melanoma [178-180]. This increased IFP is due not only to fluid failing to properly drain out of the interstitial space, but also to a number of other physiological changes in the tumor microenvironment, including both an increased number of tumor cells and more ECM deposition in the tumor stroma.

Recent studies support tumor microenvironment stiffness as a therapeutic target aimed at preventing cancer development and progression [181-184]. The tumor stromal region typically consists of excessive amounts of fibrous collagen, which can be cross-linked by soluble mediators, such as lysyl oxidase (LOX), thereby increasing the stiffness of the tumor microenvironment [185-187]. In turn, this increased tumor stiffness is considered to profoundly influence tumor progression inducing activated oncogenic signal pathways driven by activated FAK, Akt, $\beta$-catenin, and PI3K, as well as the inhibition of tumor suppressor molecules, such as PTEN. Targeting tumor stiffness via the inhibition of LOX enzymatic activity has been demonstrated to decrease metastatic dissemination of breast and colorectal tumor cells in vivo $[188,189]$. Treatment with LOX-blocking antibody in combination with gemcitabine also shows attenuated metastases of early-stage pancreatic tumors in Pdx1-Cre 
KrasG12D/+ Trp53R172H/+ (KPC) mice, however, the effects are not observed in late-stage tumors, presumably due to the presence of considerable levels of already established cross-linked collagen [190].

In pancreatic cancers, tumor cells secrete Hedgehog ( $\mathrm{Hh}$ ) ligands to act on a patched (PTCH1) receptor expressed in CAFs. Hh signaling is thus activated by the ligand binding to PTCH1 that relieves an inhibitory effect on Smoothened (SMO) in these fibroblasts [191]. Hh signaling in CAFs coordinates the acquisition of a poorly-vascularized, desmoplastic microenvironment which impairs drug delivery in pancreatic adenocarcinoma [192-194]. Suppression of the stromal Hh signal by the inhibitor of SMO improves the delivery of gemcitabine via transiently increasing vascular density of pancreatic tumors in KPC mice [194].

Increased tumor stiffness impacts not only tumor cells, but also similarly exerts its effects on the surrounding stromal cells, wherein tumor stiffness activates normal fibroblasts to acquire CAF phenotypes and maintains them by the nuclear localization of yes-associated protein (YAP) in the Hippo signal pathway [195-198]. Actomyosin contractility and Src function are required for YAP activation by stiff matrices. Conversely, YAP depletion reduces the ability of CAFs to form fibrous collagen networks and to promote angiogenesis in vivo. YAP regulates expression levels of several cytoskeleton-related molecules including ANLN and DIAPH3 and then stabilizes MLC2/MYL9. Matrix stiffness further enhances YAP activation, thereby establishing a feed-forward self-reinforcing loop which helps to maintain the CAF phenotype [198]. Increased YAP1 activity in CAFs thus also induces a stiff ECM associated with the Rho-ROCK axis, thereby activating both SrC and YAP signaling in a self-stimulating manner.

\subsection{Therapeutic Strategy Against Activated Tumor Stroma}

As noted above, CAFs compromise the effects of cancer therapies not only by producing large amounts of tumor-promoting growth factors and inflammatory cytokines, but also by recruiting other stromal cell types including immunosuppressive inflammatory cells into tumors. Nonetheless, as clonal somatic genetic alterations are rarely harbored in CAFs of different human carcinomas and these fibroblasts are anticipated to be less likely than carcinoma cells to acquire resistance to therapy [199], CAFs are speculated to be a promising therapeutic target $[50,200,201]$.

Treatment with chemotherapy significantly eradicates chemosensitive tumors. However, a considerable number of CAFs often survive in the remnant tumors after treatment. The surviving CAFs acquire innate and adaptive therapeutic resistance that are accompanied by stromal inflammation and increased collagen accumulation, leading to iatrogenic tumor stiffness and the development of chemoresistant tumors. Treatment with several drugs in combination with chemotherapy shows promising results compromising the CAF-induced drug resistance in murine tumor models (Figure 5).

Aberrant IFP elevation disrupts the distribution of systemically administered anti-cancer drugs and thereby compromises the treatment of solid tumors [171,172,202,203]. Hyaluronidases are enzymes that catalyze the degradation of hyaluronic acid (HA), a glycosaminoglycan distributed widely throughout various different tissues. Pegylated recombinant hyaluronidase, known as PEGPH20, contributes to the significant decrease in IFP, thus improving gemcitabine sensitivity in pancreatic ductal adenocarcinoma (PDAC) [204-206]. PEGPH20 reportedly reduces IFP in the PDAC microenvironment and expands the tumor vasculature to improve perfusion, which increases access for anti-tumor immune cells and therapeutic agents. A randomized phase II study was also performed using a total of 279 patients with previously untreated metastatic pancreatic ductal adenocarcinoma treated with chemotherapy alone or chemotherapy plus PEGPH20 [207]. The results demonstrated that PEGPH20 treatment is more beneficial in patients with HA-high tumors than in those with HA-low tumors. The level of HA in the tumor-associated stroma was also shown to be a promising biomarker for identifying patients who may benefit from PEGPH20 treatment [207]. 


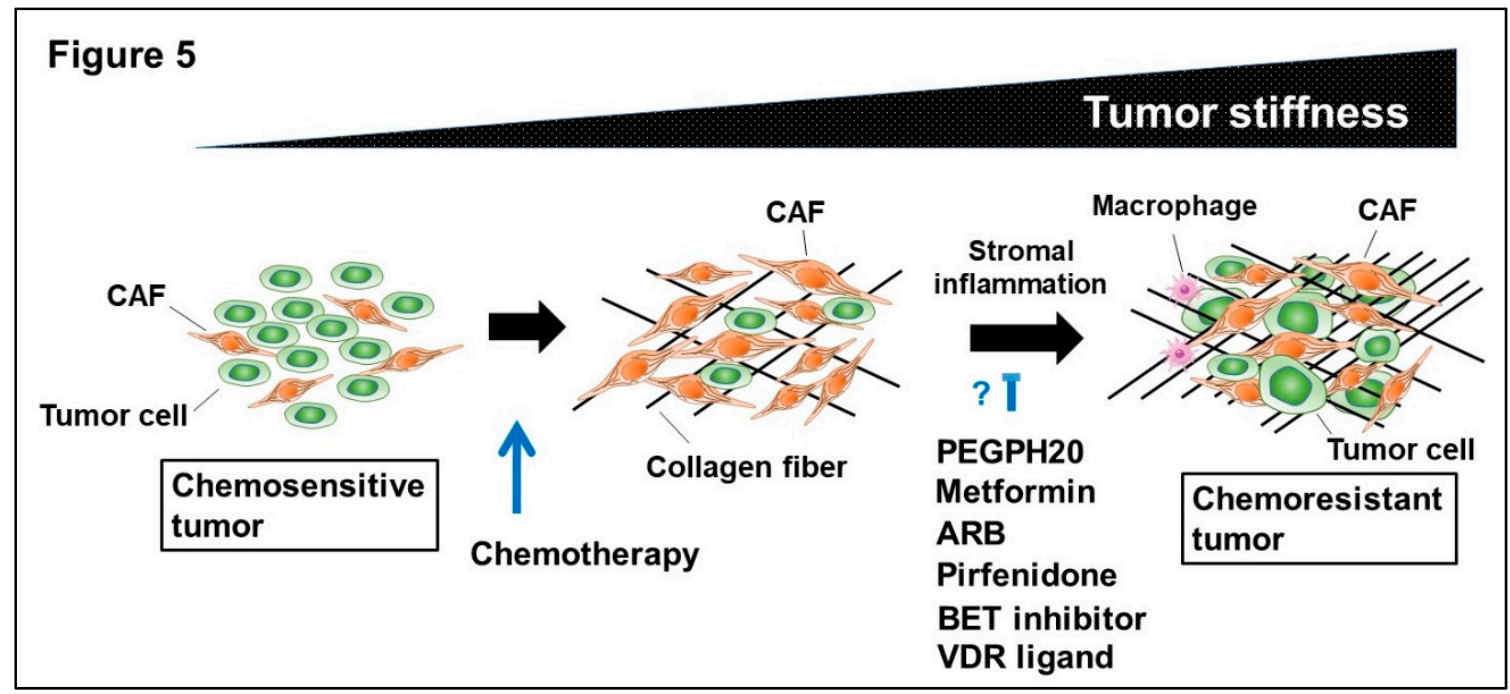

Figure 5. Schematic representation of chemoresistant tumor formation by CAFs and the potential treatment.

Metformin is an oral drug used in the management of patients with type II DM. Metformin administration was first reported to likely be associated with a reduced risk of cancer in the DM patients more than a decade ago [208]. Recently, mounting evidence has pointed to its anti-cancer effects in various malignancies [209-211]. This is a typical example of drug re-positioning [212]. Metformin has been reported to play a suppressor role in inflammatory and fibrosis-related diseases, such as atherosclerosis, cardiac fibrosis, renal fibrosis, interstitial pulmonary fibrosis and endometriosis [213-216]. Inhibition of TGF- $\beta$ signal pathway, monocyte-to-macrophage differentiation, and NFKB-mediated inflammatory factors is involved in the molecular mechanisms underlying these non-malignant diseases. Importantly, similar mechanisms of metformin action have been suggested to contribute to suppression of the stromal reaction in tumors. In lung cancer, metformin was demonstrated to suppress pulmonary interstitial fibrosis during gefitinib therapy [217]. In ovarian cancer patients, cisplatin administration increases IL-6-producing myofibroblastic CAFs populations through activation of NFKB signal pathway in the tumor-associated stroma [218]. Pretreatment with metformin actually inhibits the desmoplastic stromal reaction via attenuation of the NFKB signal and IL-6 secretion from CAFs. This explains how the IL-6 receptor antagonist, which has conventionally been used for treating rheumatoid arthritis, might serve as an anti-cancer agent in clinical settings.

Renin-angiotensin system inhibitors, which have been prescribed for the treatment of cardiovascular diseases, receive considerable attention in oncology [219]. Angiotensin II (AngII) /AngII type I receptor (AT1R) axis plays pivotal roles in promoting tumor growth and progression. The treatment of CAFs with losartan, which is a selective AT1R blocker (ARB), reportedly attenuates activated fibroblastic state, as exemplified by TGF- $\beta$ signaling and $\alpha$-SMA expression, as well as ECM production in culture [220]. Importantly, in mice orthotopically bearing breast cancer cells chemotherapy in combination with losartan inhibits tumor growth and increases survival of the mice more significantly than monotherapy does [219-221].

Pirfenidone is an orally active synthetic anti-fibrotic agent structurally similar to pyridine 2,4-dicarboxylate [222]. This drug was recently approved for the treatment of patients with IPF. Pirfenidone exerts anti-fibrotic effects through inhibition of TGF- $\beta$ and Hh signaling in lung fibroblasts of IPF patients [223]. Miura et al. recently reported that pirfenidone is likely to reduce the risk of lung cancer development in patients with IPF [224]. The retrospective analysis also demonstrated lung cancer incidence to be significantly lower in a pirfenidone-treated group than in a non-pirfenidone-treated group. Indeed, this anti-fibrotic agent induces apoptotic cell death of CAFs residing among NSCLC cells [225] and decreases the expression of collagen triple helix repeat containing 1 (CTHRC1), 
which is associated with tumor aggressiveness and poor clinical outcomes for NSCLC patients [226]. Importantly, simultaneous co-administration of pirfenidone with chemotherapy inhibits tumor growth and metastasis of breast and pancreatic carcinoma cells, presumably due to attenuation of the TGF- $\beta$ signal pathway, activated fibroblastic state and ECM protein production in CAFs [227-229].

Bromodomain-containing protein 4 (BRD4), a bromodomain and extra-terminal (BET) family member is an important epigenetic reader. BRD4 is critical for the activated fibroblastic state and enhancer-mediated profibrotic gene expression in both HSCs and CAFs [230,231]. Several investigations also show that treatment with a small molecule inhibitor of BRD4 significantly attenuates fibrosis and tumorigenesis via inhibition of stromal TGF- $\beta$ signaling in murine liver fibrosis models $[230,232]$ as well as patient-derived pancreas and skin squamous cell carcinoma models $[231,233]$.

Experimental evidence supports that the VDR signaling suppresses TGF- $\beta$-Smad $2 / 3$ signaling to attenuate the fibrotic reactions in fibrosis and tumor stroma [234]. Treatment with VDR ligands thus inhibits the activated state of HSCs and CAFs in murine liver fibrosis [235] and pancreatic carcinoma [236] models. This anti-fibrotic effect is due to the inhibition of the Smad3 recruitment into the binding sites of cis-regulatory regions in the profibrotic genes.

Taken together, these findings indicate that several anti-fibrosis drugs have major potential for impairing and even blocking tumor-promoting CAFs, resulting in attenuation of tumor growth and progression in experimental animal models.

\section{Closing Remarks}

In this review, we have described the close relationship between tumorigenesis and fibrosis, both of which are accompanied by the expansion of activated fibroblast populations. Several aspects of the cellular mechanisms underlying CAF-promoted tumorigenesis and therapy-resistance have been elucidated. However, there are CAF populations that have surprisingly been shown to suppress tumor growth and progression in different murine tumor models including those of the pancreas, bladder and colon [237-240]. These studies indicate that activation of Hh signaling in CAFs by tumor cell-produced Hh ligand suppresses the growth of tumors via bone morphogenetic protein (BMP) signaling in tumor cells, suggesting the presence of CAF populations with tumor-suppressive functions. In marked contrast, a very recent study using murine models of TNBC found that Hh signaling in CAFs promotes cancer stem cell plasticity and chemoresistance in cancer cells via elevation of stromal FGF5 production [182]. These contradictory observations raise the possibility of cancer cell context-dependent differences in stromal Hh signaling. Although tumor-suppressive or -promoting functions may be inherent in fibroblasts within tumors due to their multiple cells-of-origin, their complex interactions with other stromal cells and carcinoma cells with genetically and epigenetically diverse alterations would also presumably be crucial for generating CAF heterogeneity during tumor progression. Thus, CAFs can reasonably be described as a "cell state" rather than a "cell type" [241].

Several growth factors and cytokines have been identified as inducing CAF differentiation in progenitors, some of which consist of the feedback loop between cancer cells and CAFs in the tumor microenvironment. CAFs also stably maintain their transcriptome and metabolic profiling in an autocrine fashion. It is noteworthy that activated and tumor-promoting traits in these fibroblasts are retained during in vitro propagations, despite a lack of ongoing interactions with carcinoma cells, suggesting the key roles of epigenetic alterations in CAFs, as exemplified by DNA methylation [65]. Given that CAFs are responsible for high IFP in the tumor microenvironment, therapies aimed at preventing iatrogenic tumor stiffness hold great promise. Furthermore, it is remarkable that pirfenidone, one of the anti-fibrotic drugs, not only prevents IPF-associated lung cancer development but also inhibits the distant metastasis of difficult-to-cure breast carcinoma. However, the molecular mechanisms which would allow anti-cancer therapies to precisely target CAFs have yet to be elucidated. The importance of targeting the tumor stroma as well as tumor cells themselves has attracted increasing academic attention as researchers strive to achieve the precision medicine. 
Funding: We gratefully acknowledge Grants-in-Aid for Scientific Research from the Ministry of Education, Culture, Sports, Science and Technology, Japan (Research Project Number: 18K07207 and 15K14385 to A.O.) and a Grant-in-Aid (S1311011) from the Foundation of Strategic Research Projects in Private Universities from the MEXT, Japan (A.O.)

Acknowledgments: The authors apologize to researchers whose work is not cited due to space limitations. We appreciate Ms. Chie Kataoka for proofreading and editing this manuscript.

Conflicts of Interest: The authors have no conflicts of interest to declare.

\section{Abbreviations}

\begin{tabular}{|c|c|}
\hline AngII & angiotensin II \\
\hline $\mathrm{ARB}$ & angiotensin II type I receptor blocker \\
\hline AT1R & angII type I receptor \\
\hline$\alpha-S M A$ & $\alpha$-smooth muscle actin \\
\hline BRD4 & Bromodomain-containing protein 4 \\
\hline CAFs & carcinoma-associated fibroblasts \\
\hline CAV1 & caveolin 1 \\
\hline $\mathrm{c}-\mathrm{Abl}$ & c-Abl protein kinase \\
\hline CSF1 & colony-stimulating factor 1 \\
\hline $\mathrm{DM}$ & diabetes mellitus \\
\hline ECM & extracellular matrix \\
\hline EGF & epithelial growth factor \\
\hline EGFR & epidermal growth factor receptor \\
\hline EMT & epithelial-mesenchymal transition \\
\hline EndoMT & endothelial-mesenchymal transition \\
\hline EPCs & endothelial precursor cells \\
\hline ERK & extracellular signal-regulated kinase \\
\hline FAK & focal adhesion kinase \\
\hline FGF & fibroblast growth factor \\
\hline FGFRs & fibroblast growth factor receptors \\
\hline GSK-3 $\beta$ & glycogen synthase kinase $-3 \beta$ \\
\hline HA & hyaluronic acid \\
\hline $\mathrm{HCC}$ & hepatocellular carcinoma \\
\hline HGF & hepatocyte growth factor \\
\hline $\mathrm{Hh}$ & Hedgehog \\
\hline HIC1 & hypermethylated in cancer 1 \\
\hline HIF- $1 \alpha$ & hypoxia-induced factor- $1 \alpha$ \\
\hline HSCs & hepatic stellate cells \\
\hline IFP & interstitial fluid pressures \\
\hline IGF1R & insulin-like growth factor 1 receptor \\
\hline IGF2 & insulin-like growth factor 2 \\
\hline IL & interleukin \\
\hline IPF & idiopathic pulmonary fibrosis \\
\hline IR & insulin receptor \\
\hline JAK1 & Janus kinase 1 \\
\hline LIF & leukemia inhibitory factor \\
\hline LOX & lysyl oxidase \\
\hline MAPK & mitogen-activate protein kinase \\
\hline MCT & monocarboxylate transporter \\
\hline MLC & myosin light chain \\
\hline MMP & matrix metalloproteinase \\
\hline MSCs & mesenchymal stem cells \\
\hline mTOR & mammalian target of rapamycin \\
\hline NASH & non-alcoholic steatohepatitis \\
\hline
\end{tabular}




\begin{tabular}{|c|c|}
\hline NSCLC & non-small cell lung cancer \\
\hline PAI-1 & plasminogen activator inhibitor-1 \\
\hline PDAC & pancreatic ductal adenocarcinoma \\
\hline PDGF & platelet-derived growth factor \\
\hline PDGFR & platelet-derived growth factor receptor \\
\hline $\mathrm{PGE}_{2}$ & prostaglandin $\mathrm{E}_{2}$ \\
\hline PI3K & phosphatidylinositol-3 kinase \\
\hline PIP3 & phosphatidylinositol-3,4,5-triphosphate \\
\hline PKC- $\delta$ & protein kinase $C \delta$ \\
\hline KPC & Pdx1-Cre KrasG12D/+ Trp53R172H/+ \\
\hline PMN-MDSCs & polymorpho-nuclear myeloid-derived suppressor cells \\
\hline PTEN & phosphatase and tensin homologue deleted on chromosome 10 \\
\hline ROCK & Rho-associated protein kinase \\
\hline ROS & reactive oxygen species \\
\hline SASP & senescence-associated secretory phenotype \\
\hline SHP-1 & src homology region 2 domain-containing phosphatase- 1 \\
\hline SDF-1 & stromal cell-derived factor-1 \\
\hline $\mathrm{SMO}$ & Smoothened \\
\hline SPARC & secreted protein acidic and rich in cysteine \\
\hline STAT3 & signal transducer and activator of transcription 3 \\
\hline STC1 & stanniocalcin 1 \\
\hline TAMs & tumor-associated macrophages \\
\hline TCA & tricarboxylic acid \\
\hline TGF- $\beta$ & transforming growth factor- $\beta$ \\
\hline TKI & tyrosine kinase inhibitor \\
\hline TNBC & triple-negative breast carcinoma \\
\hline TIC & tumor-initiating cells \\
\hline uPA & urokinase-type plasminogen activator \\
\hline VDR & vitamin D receptor \\
\hline VEGF & vascular endothelial growth factor \\
\hline WNT16B & Wnt family member wingless-type MMTV integration site family member $16 \mathrm{~B}$ \\
\hline YAP & yes-associated protein \\
\hline
\end{tabular}

\section{References}

1. Hinz, B. Formation and function of the myofibroblast during tissue repair. J. Invest. Dermatol. 2007, 127, 526-537. [CrossRef]

2. Thannickal, V.J.; Lee, D.Y.; White, E.S.; Cui, Z.; Larios, J.M.; Chacon, R.; Horowitz, J.C.; Day, R.M.; Thomas, P.E. Myofibroblast differentiation by transforming growth factor-beta1 is dependent on cell adhesion and integrin signaling via focal adhesion kinase. J. Biol. Chem. 2003, 278, 12384-12389. [CrossRef] [PubMed]

3. Scharenberg, M.A.; Pippenger, B.E.; Sack, R.; Zingg, D.; Ferralli, J.; Schenk, S.; Martin, I.; Chiquet-Ehrismann, R. TGF-beta-induced differentiation into myofibroblasts involves specific regulation of two MKL1 isoforms. J. Cell Sci. 2014, 127, 1079-1091. [CrossRef]

4. Foster, D.S.; Jones, R.E.; Ransom, R.C.; Longaker, M.T.; Norton, J.A. The evolving relationship of wound healing and tumor stroma. JCI Insight 2018, 3, e99911. [CrossRef]

5. Carthy, J.M. TGFbeta signaling and the control of myofibroblast differentiation: Implications for chronic inflammatory disorders. J. Cell Physiol. 2018, 233, 98-106. [CrossRef] [PubMed]

6. Wipff, P.J.; Rifkin, D.B.; Meister, J.J.; Hinz, B. Myofibroblast contraction activates latent TGF-beta1 from the extracellular matrix. J. Cell Biol. 2007, 179, 1311-1323. [CrossRef] [PubMed]

7. Wynn, T.A.; Ramalingam, T.R. Mechanisms of fibrosis: Therapeutic translation for fibrotic disease. Nat. Med. 2012, 18, 1028-1040. [CrossRef] [PubMed]

8. Uehara, T.; Ainslie, G.R.; Kutanzi, K.; Pogribny, I.P.; Muskhelishvili, L.; Izawa, T.; Yamate, J.; Kosyk, O.; Shymonyak, S.; Bradford, B.U.; et al. Molecular mechanisms of fibrosis-associated promotion of liver carcinogenesis. Toxicol. Sci. 2013, 132, 53-63. [CrossRef] [PubMed] 
9. Lederer, D.J.; Martinez, F.J. Idiopathic Pulmonary Fibrosis. N. Engl. J. Med. 2018, 378, 1811-1823. [CrossRef] [PubMed]

10. Zhao, M.; Dumur, C.I.; Holt, S.E.; Beckman, M.J.; Elmore, L.W. Multipotent adipose stromal cells and breast cancer development: Think globally, act locally. Mol. Carcinog 2010, 49, 923-927. [CrossRef] [PubMed]

11. Cox, T.R.; Erler, J.T. Molecular pathways: Connecting fibrosis and solid tumor metastasis. Clin. Cancer Res. 2014, 20, 3637-3643. [CrossRef] [PubMed]

12. Yoon, J.H.; Nouraie, M.; Chen, X.; Zou, R.H.; Sellares, J.; Veraldi, K.L.; Chiarchiaro, J.; Lindell, K.; Wilson, D.O.; Kaminski, N.; et al. Characteristics of lung cancer among patients with idiopathic pulmonary fibrosis and interstitial lung disease-Analysis of institutional and population data. Respir. Res. 2018, 19, 195. [CrossRef] [PubMed]

13. Tomassetti, S.; Gurioli, C.; Ryu, J.H.; Decker, P.A.; Ravaglia, C.; Tantalocco, P.; Buccioli, M.; Piciucchi, S.; Sverzellati, N.; Dubini, A.; et al. The impact of lung cancer on survival of idiopathic pulmonary fibrosis. Chest 2015, 147, 157-164. [CrossRef] [PubMed]

14. Wong, S.L.; Sukkar, M.B. The SPARC protein: An overview of its role in lung cancer and pulmonary fibrosis and its potential role in chronic airways disease. Br. J. Pharmacol. 2017, 174, 3-14. [CrossRef] [PubMed]

15. Trombetta-Esilva, J.; Bradshaw, A.D. The Function of SPARC as a Mediator of Fibrosis. Open Rheumatol. J. 2012, 6, 146-155. [CrossRef] [PubMed]

16. Hohenester, E.; Sasaki, T.; Giudici, C.; Farndale, R.W.; Bachinger, H.P. Structural basis of sequence-specific collagen recognition by SPARC. Proc. Natl. Acad. Sci. USA 2008, 105, 18273-18277. [CrossRef]

17. Chang, W.; Wei, K.; Jacobs, S.S.; Upadhyay, D.; Weill, D.; Rosen, G.D. SPARC suppresses apoptosis of idiopathic pulmonary fibrosis fibroblasts through constitutive activation of beta-catenin. J. Biol. Chem. 2010, 285, 8196-8206. [CrossRef]

18. Francki, A.; McClure, T.D.; Brekken, R.A.; Motamed, K.; Murri, C.; Wang, T.; Sage, E.H. SPARC regulates TGF-beta1-dependent signaling in primary glomerular mesangial cells. J. Cell Biochem. 2004, 91, 915-925. [CrossRef]

19. Koukourakis, M.I.; Giatromanolaki, A.; Brekken, R.A.; Sivridis, E.; Gatter, K.C.; Harris, A.L.; Sage, E.H. Enhanced expression of SPARC/osteonectin in the tumor-associated stroma of non-small cell lung cancer is correlated with markers of hypoxia/acidity and with poor prognosis of patients. Cancer Res. 2003, 63, 5376-5380.

20. Infante, J.R.; Matsubayashi, H.; Sato, N.; Tonascia, J.; Klein, A.P.; Riall, T.A.; Yeo, C.; Iacobuzio-Donahue, C.; Goggins, M. Peritumoral fibroblast SPARC expression and patient outcome with resectable pancreatic adenocarcinoma. J. Clin. Oncol. 2007, 25, 319-325. [CrossRef]

21. Said, N.; Frierson, H.F.; Sanchez-Carbayo, M.; Brekken, R.A.; Theodorescu, D. Loss of SPARC in bladder cancer enhances carcinogenesis and progression. J. Clin. Investig. 2013, 123, 751-766. [CrossRef]

22. Baffy, G.; Brunt, E.M.; Caldwell, S.H. Hepatocellular carcinoma in non-alcoholic fatty liver disease: An emerging menace. J. Hepatol. 2012, 56, 1384-1391. [CrossRef]

23. Lade, A.; Noon, L.A.; Friedman, S.L. Contributions of metabolic dysregulation and inflammation to nonalcoholic steatohepatitis, hepatic fibrosis, and cancer. Curr. Opin. Oncol. 2014, 26, 100-107. [CrossRef]

24. Monga, S.P. beta-Catenin Signaling and Roles in Liver Homeostasis, Injury, and Tumorigenesis. Gastroenterology 2015, 148, 1294-1310. [CrossRef]

25. Bakiri, L.; Hamacher, R.; Grana, O.; Guio-Carrion, A.; Campos-Olivas, R.; Martinez, L.; Dienes, H.P.; Thomsen, M.K.; Hasenfuss, S.C.; Wagner, E.F. Liver carcinogenesis by FOS-dependent inflammation and cholesterol dysregulation. J. Exp. Med. 2017, 214, 1387-1409. [CrossRef]

26. Chun, Y.S.; Huang, M.; Rink, L.; Von Mehren, M. Expression levels of insulin-like growth factors and receptors in hepatocellular carcinoma: A retrospective study. World J. Surg. Oncol. 2014, 12, 231. [CrossRef]

27. Enguita-German, M.; Fortes, P. Targeting the insulin-like growth factor pathway in hepatocellular carcinoma. World J. Hepatol. 2014, 6, 716-737. [CrossRef]

28. Xu, Z.; Hu, J.; Cao, H.; Pilo, M.G.; Cigliano, A.; Shao, Z.; Xu, M.; Ribback, S.; Dombrowski, F.; Calvisi, D.F.; et al. Loss of Pten synergizes with c-Met to promote hepatocellular carcinoma development via mTORC2 pathway. Exp. Mol. Med. 2018, 50, e417. [CrossRef]

29. Dvorak, H.F. Tumors: Wounds that do not heal. Similarities between tumor stroma generation and wound healing. N. Engl. J. Med. 1986, 315, 1650-1659. 
30. Schafer, M.; Werner, S. Cancer as an overhealing wound: An old hypothesis revisited. Nat. Rev. Mol. Cell Biol. 2008, 9, 628-638. [CrossRef]

31. Piera-Velazquez, S.; Li, Z.; Jimenez, S.A. Role of endothelial-mesenchymal transition (EndoMT) in the pathogenesis of fibrotic disorders. Am. J. Pathol. 2011, 179, 1074-1080. [CrossRef] [PubMed]

32. Piera-Velazquez, S.; Mendoza, F.A.; Jimenez, S.A. Endothelial to Mesenchymal Transition (EndoMT) in the Pathogenesis of Human Fibrotic Diseases. J. Clin. Med. 2016, 5, 45. [CrossRef] [PubMed]

33. LeBleu, V.S.; Kalluri, R. A peek into cancer-associated fibroblasts: Origins, functions and translational impact. Dis Model. Mech 2018, 11, dmm029447. [CrossRef] [PubMed]

34. Kalluri, R.; Weinberg, R.A. The basics of epithelial-mesenchymal transition. J. Clin. Investig. 2009, 119, 1420-1428. [CrossRef] [PubMed]

35. Kokudo, T.; Suzuki, Y.; Yoshimatsu, Y.; Yamazaki, T.; Watabe, T.; Miyazono, K. Snail is required for TGFbeta-induced endothelial-mesenchymal transition of embryonic stem cell-derived endothelial cells. J. Cell Sci. 2008, 121, 3317-3324. [CrossRef]

36. Medici, D.; Potenta, S.; Kalluri, R. Transforming growth factor-beta2 promotes Snail-mediated endothelial-mesenchymal transition through convergence of Smad-dependent and Smad-independent signalling. Biochem. J. 2011, 437, 515-520. [CrossRef]

37. Batlle, E.; Sancho, E.; Franci, C.; Dominguez, D.; Monfar, M.; Baulida, J.; Garcia De Herreros, A. The transcription factor snail is a repressor of E-cadherin gene expression in epithelial tumour cells. Nat. Cell Biol. 2000, 2, 84-89. [CrossRef]

38. Li, Z.; Jimenez, S.A. Protein kinase Cdelta and c-Abl kinase are required for transforming growth factor beta induction of endothelial-mesenchymal transition in vitro. Arthritis Rheumatol. 2011, 63, 2473-2483. [CrossRef]

39. Hinz, B.; Phan, S.H.; Thannickal, V.J.; Prunotto, M.; Desmouliere, A.; Varga, J.; De Wever, O.; Mareel, M.; Gabbiani, G. Recent developments in myofibroblast biology: Paradigms for connective tissue remodeling. Am. J. Pathol. 2012, 180, 1340-1355. [CrossRef]

40. Hudson, L.G.; Newkirk, K.M.; Chandler, H.L.; Choi, C.; Fossey, S.L.; Parent, A.E.; Kusewitt, D.F. Cutaneous wound reepithelialization is compromised in mice lacking functional Slug (Snai2). J. Dermatol. Sci. 2009, 56, 19-26. [CrossRef]

41. Savagner, P.; Kusewitt, D.F.; Carver, E.A.; Magnino, F.; Choi, C.; Gridley, T.; Hudson, L.G. Developmental transcription factor slug is required for effective re-epithelialization by adult keratinocytes. J. Cell Physiol. 2005, 202, 858-866. [CrossRef]

42. Arpino, V.; Brock, M.; Gill, S.E. The role of TIMPs in regulation of extracellular matrix proteolysis. Matrix Biol. 2015, 44-46, 247-254. [CrossRef]

43. Vered, M.; Dayan, D.; Yahalom, R.; Dobriyan, A.; Barshack, I.; Bello, I.O.; Kantola, S.; Salo, T. Cancer-associated fibroblasts and epithelial-mesenchymal transition in metastatic oral tongue squamous cell carcinoma. Int. J. Cancer 2010, 127, 1356-1362. [CrossRef]

44. Hassona, Y.; Cirillo, N.; Heesom, K.; Parkinson, E.K.; Prime, S.S. Senescent cancer-associated fibroblasts secrete active MMP-2 that promotes keratinocyte dis-cohesion and invasion. Br. J. Cancer 2014, 111, 1230-1237. [CrossRef]

45. Tian, B.; Chen, X.; Zhang, H.; Li, X.; Wang, J.; Han, W.; Zhang, L.Y.; Fu, L.; Li, Y.; Nie, C.; et al. Urokinase plasminogen activator secreted by cancer-associated fibroblasts induces tumor progression via PI3K/AKT and ERK signaling in esophageal squamous cell carcinoma. Oncotarget 2017, 8, 42300-42313. [CrossRef]

46. Yamaguchi, Y.; Mann, D.M.; Ruoslahti, E. Negative regulation of transforming growth factor-beta by the proteoglycan decorin. Nature 1990, 346, 281-284. [CrossRef]

47. Imai, K.; Hiramatsu, A.; Fukushima, D.; Pierschbacher, M.D.; Okada, Y. Degradation of decorin by matrix metalloproteinases: Identification of the cleavage sites, kinetic analyses and transforming growth factor-beta1 release. Biochem. J. 1997, 322 Pt 3, 809-814. [CrossRef]

48. Gascard, P.; Tlsty, T.D. Carcinoma-associated fibroblasts: Orchestrating the composition of malignancy. Genes Dev. 2016, 30, 1002-1019. [CrossRef]

49. Mezawa, Y.; Orimo, A. The roles of tumor- and metastasis-promoting carcinoma-associated fibroblasts in human carcinomas. Cell Tissue Res. 2016, 365, 675-689. [CrossRef]

50. Pietras, K.; Ostman, A. Hallmarks of cancer: Interactions with the tumor stroma. Exp. Cell Res. 2010, 316, 1324-1331. [CrossRef] 
51. Heneberg, P. Paracrine tumor signaling induces transdifferentiation of surrounding fibroblasts. Crit. Rev. Oncol. Hematol. 2016, 97, 303-311. [CrossRef]

52. Tao, L.; Huang, G.; Song, H.; Chen, Y.; Chen, L. Cancer associated fibroblasts: An essential role in the tumor microenvironment. Oncol. Lett. 2017, 14, 2611-2620. [CrossRef]

53. Polanska, U.M.; Orimo, A. Carcinoma-associated fibroblasts: Non-neoplastic tumour-promoting mesenchymal cells. J. Cell Physiol. 2013, 228, 1651-1657. [CrossRef]

54. Kalluri, R. The biology and function of fibroblasts in cancer. Nat. Rev. Cancer 2016, 16, 582-598. [CrossRef]

55. Ohlund, D.; Elyada, E.; Tuveson, D. Fibroblast heterogeneity in the cancer wound. J. Exp. Med. 2014, 211, 1503-1523. [CrossRef]

56. Mishra, P.J.; Mishra, P.J.; Humeniuk, R.; Medina, D.J.; Alexe, G.; Mesirov, J.P.; Ganesan, S.; Glod, J.W.; Banerjee, D. Carcinoma-associated fibroblast-like differentiation of human mesenchymal stem cells. Cancer Res. 2008, 68, 4331-4339. [CrossRef]

57. Karnoub, A.E.; Dash, A.B.; Vo, A.P.; Sullivan, A.; Brooks, M.W.; Bell, G.W.; Richardson, A.L.; Polyak, K.; Tubo, R.; Weinberg, R.A. Mesenchymal stem cells within tumour stroma promote breast cancer metastasis. Nature 2007, 449, 557-563. [CrossRef]

58. Raz, Y.; Cohen, N.; Shani, O.; Bell, R.E.; Novitskiy, S.V.; Abramovitz, L.; Levy, C.; Milyavsky, M.; Leider-Trejo, L.; Moses, H.L.; et al. Bone marrow-derived fibroblasts are a functionally distinct stromal cell population in breast cancer. J. Exp. Med. 2018, 215, 3075-3093. [CrossRef]

59. Midgley, A.C.; Rogers, M.; Hallett, M.B.; Clayton, A.; Bowen, T.; Phillips, A.O.; Steadman, R. Transforming growth factor-beta1 (TGF-beta1)-stimulated fibroblast to myofibroblast differentiation is mediated by hyaluronan (HA)-facilitated epidermal growth factor receptor (EGFR) and CD44 co-localization in lipid rafts. J. Biol. Chem. 2013, 288, 14824-14838. [CrossRef]

60. Bonner, J.C. Regulation of PDGF and its receptors in fibrotic diseases. Cytokine Growth Factor Rev. 2004, 15, 255-273. [CrossRef]

61. Avgustinova, A.; Iravani, M.; Robertson, D.; Fearns, A.; Gao, Q.; Klingbeil, P.; Hanby, A.M.; Speirs, V.; Sahai, E.; Calvo, F.; et al. Tumour cell-derived Wnt7a recruits and activates fibroblasts to promote tumour aggressiveness. Nat. Commun. 2016, 7, 10305. [CrossRef]

62. Biffi, G.; Oni, T.E.; Spielman, B.; Hao, Y.; Elyada, E.; Park, Y.; Preall, J.; Tuveson, D.A. IL1-Induced JAK/STAT Signaling Is Antagonized by TGFbeta to Shape CAF Heterogeneity in Pancreatic Ductal Adenocarcinoma. Cancer Discov. 2019, 9, 282-301. [CrossRef]

63. Sharon, Y.; Raz, Y.; Cohen, N.; Ben-Shmuel, A.; Schwartz, H.; Geiger, T.; Erez, N. Tumor-derived osteopontin reprograms normal mammary fibroblasts to promote inflammation and tumor growth in breast cancer. Cancer Res. 2015, 75, 963-973. [CrossRef]

64. Sanz-Moreno, V.; Gaggioli, C.; Yeo, M.; Albrengues, J.; Wallberg, F.; Viros, A.; Hooper, S.; Mitter, R.; Feral, C.C.; Cook, M.; et al. ROCK and JAK1 signaling cooperate to control actomyosin contractility in tumor cells and stroma. Cancer Cell 2011, 20, 229-245. [CrossRef]

65. Albrengues, J.; Bertero, T.; Grasset, E.; Bonan, S.; Maiel, M.; Bourget, I.; Philippe, C.; Herraiz Serrano, C.; Benamar, S.; Croce, O; et al. Epigenetic switch drives the conversion of fibroblasts into proinvasive cancer-associated fibroblasts. Nat. Commun. 2015, 6, 10204. [CrossRef]

66. Shien, K.; Papadimitrakopoulou, V.A.; Ruder, D.; Behrens, C.; Shen, L.; Kalhor, N.; Song, J.; Lee, J.J.; Wang, J.; Tang, X.; et al. JAK1/STAT3 Activation through a Proinflammatory Cytokine Pathway Leads to Resistance to Molecularly Targeted Therapy in Non-Small Cell Lung Cancer. Mol. Cancer Ther. 2017, 16, 2234-2245. [CrossRef]

67. Zhang, Q.; Wang, H.Y.; Marzec, M.; Raghunath, P.N.; Nagasawa, T.; Wasik, M.A. STAT3- and DNA methyltransferase 1-mediated epigenetic silencing of SHP-1 tyrosine phosphatase tumor suppressor gene in malignant T lymphocytes. Proc. Natl. Acad. Sci. USA 2005, 102, 6948-6953. [CrossRef]

68. Lee, H.; Zhang, P.; Herrmann, A.; Yang, C.; Xin, H.; Wang, Z.; Hoon, D.S.; Forman, S.J.; Jove, R.; Riggs, A.D.; et al. Acetylated STAT3 is crucial for methylation of tumor-suppressor gene promoters and inhibition by resveratrol results in demethylation. Proc. Natl. Acad. Sci. USA 2012, 109, 7765-7769. [CrossRef]

69. Iwabu, A.; Smith, K.; Allen, F.D.; Lauffenburger, D.A.; Wells, A. Epidermal growth factor induces fibroblast contractility and motility via a protein kinase C delta-dependent pathway. J. Biol. Chem. 2004, 279, 14551-14560. [CrossRef] 
70. Mink, S.R.; Vashistha, S.; Zhang, W.; Hodge, A.; Agus, D.B.; Jain, A. Cancer-associated fibroblasts derived from EGFR-TKI-resistant tumors reverse EGFR pathway inhibition by EGFR-TKIs. Mol. Cancer Res. 2010, 8 , 809-820. [CrossRef]

71. Yun, Y.R.; Won, J.E.; Jeon, E.; Lee, S.; Kang, W.; Jo, H.; Jang, J.H.; Shin, U.S.; Kim, H.W. Fibroblast growth factors: Biology, function, and application for tissue regeneration. J. Tissue Eng. 2010, 2010, 218142. [CrossRef]

72. Bai, Y.P.; Shang, K.; Chen, H.; Ding, F.; Wang, Z.; Liang, C.; Xu, Y.; Sun, M.H.; Li, Y.Y. FGF-1/-3/FGFR4 signaling in cancer-associated fibroblasts promotes tumor progression in colon cancer through Erk and MMP-7. Cancer Sci. 2015, 106, 1278-1287. [CrossRef]

73. Mori, T.; Miyamoto, T.; Yoshida, H.; Asakawa, M.; Kawasumi, M.; Kobayashi, T.; Morioka, H.; Chiba, K.; Toyama, Y.; Yoshimura, A. IL-1beta and TNFalpha-initiated IL-6-STAT3 pathway is critical in mediating inflammatory cytokines and RANKL expression in inflammatory arthritis. Int. Immunol. 2011, 23, 701-712. [CrossRef]

74. Tsuyada, A.; Chow, A.; Wu, J.; Somlo, G.; Chu, P.; Loera, S.; Luu, T.; Li, A.X.; Wu, X.; Ye, W.; et al. CCL2 mediates cross-talk between cancer cells and stromal fibroblasts that regulates breast cancer stem cells. Cancer Res. 2012, 72, 2768-2779. [CrossRef]

75. Albrengues, J.; Bourget, I.; Pons, C.; Butet, V.; Hofman, P.; Tartare-Deckert, S.; Feral, C.C.; Meneguzzi, G.; Gaggioli, C. LIF mediates proinvasive activation of stromal fibroblasts in cancer. Cell Rep. 2014, 7, 1664-1678. [CrossRef]

76. Li, W.; Fan, J.; Chen, M.; Guan, S.; Sawcer, D.; Bokoch, G.M.; Woodley, D.T. Mechanism of human dermal fibroblast migration driven by type I collagen and platelet-derived growth factor-BB. Mol. Biol. Cell 2004, 15, 294-309. [CrossRef]

77. Roswall, P.; Bocci, M.; Bartoschek, M.; Li, H.; Kristiansen, G.; Jansson, S.; Lehn, S.; Sjolund, J.; Reid, S.; Larsson, C.; et al. Microenvironmental control of breast cancer subtype elicited through paracrine platelet-derived growth factor-CC signaling. Nat. Med. 2018, 24, 463-473. [CrossRef]

78. Kabashima, K.; Sakabe, J.; Yoshiki, R.; Tabata, Y.; Kohno, K.; Tokura, Y. Involvement of Wnt signaling in dermal fibroblasts. Am. J. Pathol. 2010, 176, 721-732. [CrossRef]

79. Inada, M.; Takita, M.; Yokoyama, S.; Watanabe, K.; Tominari, T.; Matsumoto, C.; Hirata, M.; Maru, Y.; Maruyama, T.; Sugimoto, Y.; et al. Direct Melanoma Cell Contact Induces Stromal Cell Autocrine Prostaglandin E2-EP4 Receptor Signaling That Drives Tumor Growth, Angiogenesis, and Metastasis. J. Biol. Chem. 2015, 290, 29781-29793. [CrossRef]

80. Guo, X.; Oshima, H.; Kitmura, T.; Taketo, M.M.; Oshima, M. Stromal fibroblasts activated by tumor cells promote angiogenesis in mouse gastric cancer. J. Biol. Chem. 2008, 283, 19864-19871. [CrossRef]

81. Biernacka, A.; Dobaczewski, M.; Frangogiannis, N.G. TGF-beta signaling in fibrosis. Growth Factors 2011, 29, 196-202. [CrossRef]

82. Lohr, M.; Schmidt, C.; Ringel, J.; Kluth, M.; Muller, P.; Nizze, H.; Jesnowski, R. Transforming growth factor-beta1 induces desmoplasia in an experimental model of human pancreatic carcinoma. Cancer Res. 2001, 61, 550-555.

83. Berking, C.; Takemoto, R.; Schaider, H.; Showe, L.; Satyamoorthy, K.; Robbins, P.; Herlyn, M. Transforming growth factor-beta1 increases survival of human melanoma through stroma remodeling. Cancer Res. 2001, $61,8306-8316$.

84. Guido, C.; Whitaker-Menezes, D.; Capparelli, C.; Balliet, R.; Lin, Z.; Pestell, R.G.; Howell, A.; Aquila, S.; Ando, S.; Martinez-Outschoorn, U.; et al. Metabolic reprogramming of cancer-associated fibroblasts by TGF-beta drives tumor growth: Connecting TGF-beta signaling with "Warburg-like" cancer metabolism and L-lactate production. Cell Cycle 2012, 11, 3019-3035. [CrossRef]

85. Vaquero, J.; Lobe, C.; Tahraoui, S.; Claperon, A.; Mergey, M.; Merabtene, F.; Wendum, D.; Coulouarn, C.; Housset, C.; Desbois-Mouthon, C.; et al. The IGF2/IR/IGF1R Pathway in Tumor Cells and Myofibroblasts Mediates Resistance to EGFR Inhibition in Cholangiocarcinoma. Clin. Cancer Res. 2018, 24, 4282-4296. [CrossRef]

86. Ireland, L.; Santos, A.; Ahmed, M.S.; Rainer, C.; Nielsen, S.R.; Quaranta, V.; Weyer-Czernilofsky, U.; Engle, D.D.; Perez-Mancera, P.A.; Coupland, S.E.; et al. Chemoresistance in Pancreatic Cancer Is Driven by Stroma-Derived Insulin-Like Growth Factors. Cancer Res. 2016, 76, 6851-6863. [CrossRef] 
87. Unger, C.; Kramer, N.; Unterleuthner, D.; Scherzer, M.; Burian, A.; Rudisch, A.; Stadler, M.; Schlederer, M.; Lenhardt, D.; Riedl, A.; et al. Stromal-derived IGF2 promotes colon cancer progression via paracrine and autocrine mechanisms. Oncogene 2017, 36, 5341-5355. [CrossRef]

88. Chen, W.J.; Ho, C.C.; Chang, Y.L.; Chen, H.Y.; Lin, C.A.; Ling, T.Y.; Yu, S.L.; Yuan, S.S.; Chen, Y.J.; Lin, C.Y.; et al. Cancer-associated fibroblasts regulate the plasticity of lung cancer stemness via paracrine signalling. Nat. Commun. 2014, 5, 3472. [CrossRef]

89. Straussman, R.; Morikawa, T.; Shee, K.; Barzily-Rokni, M.; Qian, Z.R.; Du, J.; Davis, A.; Mongare, M.M.; Gould, J.; Frederick, D.T.; et al. Tumour micro-environment elicits innate resistance to RAF inhibitors through HGF secretion. Nature 2012, 487, 500-504. [CrossRef]

90. Wilson, T.R.; Fridlyand, J.; Yan, Y.; Penuel, E.; Burton, L.; Chan, E.; Peng, J.; Lin, E.; Wang, Y.; Sosman, J.; et al. Widespread potential for growth-factor-driven resistance to anticancer kinase inhibitors. Nature 2012, 487, 505-509. [CrossRef]

91. Wang, W.; Li, Q.; Yamada, T.; Matsumoto, K.; Matsumoto, I.; Oda, M.; Watanabe, G.; Kayano, Y.; Nishioka, Y.; Sone, S.; et al. Crosstalk to stromal fibroblasts induces resistance of lung cancer to epidermal growth factor receptor tyrosine kinase inhibitors. Clin. Cancer Res. 2009, 15, 6630-6638. [CrossRef]

92. Ferrara, N.; Kerbel, R.S. Angiogenesis as a therapeutic target. Nature 2005, 438, 967-974. [CrossRef]

93. Crawford, Y.; Kasman, I.; Yu, L.; Zhong, C.; Wu, X.; Modrusan, Z.; Kaminker, J.; Ferrara, N. PDGF-C mediates the angiogenic and tumorigenic properties of fibroblasts associated with tumors refractory to anti-VEGF treatment. Cancer Cell 2009, 15, 21-34. [CrossRef]

94. Erez, N.; Truitt, M.; Olson, P.; Arron, S.T.; Hanahan, D. Cancer-Associated Fibroblasts Are Activated in Incipient Neoplasia to Orchestrate Tumor-Promoting Inflammation in an NF-kappaB-Dependent Manner. Cancer Cell 2010, 17, 135-147. [CrossRef]

95. Su, S.; Chen, J.; Yao, H.; Liu, J.; Yu, S.; Lao, L.; Wang, M.; Luo, M.; Xing, Y.; Chen, F.; et al. CD10(+)GPR77(+) Cancer-Associated Fibroblasts Promote Cancer Formation and Chemoresistance by Sustaining Cancer Stemness. Cell 2018, 172, 841-856. [CrossRef]

96. Sun, Y.; Campisi, J.; Higano, C.; Beer, T.M.; Porter, P.; Coleman, I.; True, L.; Nelson, P.S. Treatment-induced damage to the tumor microenvironment promotes prostate cancer therapy resistance through WNT16B. Nat. Med. 2012, 18, 1359-1368. [CrossRef]

97. Tao, L.; Huang, G.; Wang, R.; Pan, Y.; He, Z.; Chu, X.; Song, H.; Chen, L. Cancer-associated fibroblasts treated with cisplatin facilitates chemoresistance of lung adenocarcinoma through IL-11/IL-11R/STAT3 signaling pathway. Sci. Rep. 2016, 6, 38408. [CrossRef]

98. Lotti, F.; Jarrar, A.M.; Pai, R.K.; Hitomi, M.; Lathia, J.; Mace, A.; Gantt, G.A., Jr.; Sukhdeo, K.; DeVecchio, J.; Vasanji, A.; et al. Chemotherapy activates cancer-associated fibroblasts to maintain colorectal cancer-initiating cells by IL-17A. J. Exp. Med. 2013, 210, 2851-2872. [CrossRef]

99. Erdogan, B.; Webb, D.J. Cancer-associated fibroblasts modulate growth factor signaling and extracellular matrix remodeling to regulate tumor metastasis. Biochem. Soc. Trans. 2017, 45, 229-236. [CrossRef]

100. Karagiannis, G.S.; Poutahidis, T.; Erdman, S.E.; Kirsch, R.; Riddell, R.H.; Diamandis, E.P. Cancer-associated fibroblasts drive the progression of metastasis through both paracrine and mechanical pressure on cancer tissue. Mol. Cancer Res. 2012, 10, 1403-1418. [CrossRef]

101. Hirata, E.; Girotti, M.R.; Viros, A.; Hooper, S.; Spencer-Dene, B.; Matsuda, M.; Larkin, J.; Marais, R.; Sahai, E. Intravital imaging reveals how BRAF inhibition generates drug-tolerant microenvironments with high integrin beta1/FAK signaling. Cancer Cell 2015, 27, 574-588. [CrossRef]

102. Qayyum, M.A.; Insana, M.F. Stromal responses to fractionated radiotherapy. Int. J. Radiat. Biol. 2012, 88, 383-392. [CrossRef]

103. Pazolli, E.; Alspach, E.; Milczarek, A.; Prior, J.; Piwnica-Worms, D.; Stewart, S.A. Chromatin remodeling underlies the senescence-associated secretory phenotype of tumor stromal fibroblasts that supports cancer progression. Cancer Res. 2012, 72, 2251-2261. [CrossRef]

104. Nguyen, A.H.; Elliott, I.A.; Wu, N.; Matsumura, C.; Vogelauer, M.; Attar, N.; Dann, A.; Ghukasyan, R.; Toste, P.A.; Patel, S.G.; et al. Histone deacetylase inhibitors provoke a tumor supportive phenotype in pancreatic cancer associated fibroblasts. Oncotarget 2017, 8, 19074-19088. [CrossRef] 
105. Kato, M.; Placencio-Hickok, V.R.; Madhav, A.; Haldar, S.; Tripathi, M.; Billet, S.; Mishra, R.; Smith, B.; Rohena-Rivera, K.; Agarwal, P.; et al. Heterogeneous cancer-associated fibroblast population potentiates neuroendocrine differentiation and castrate resistance in a CD105-dependent manner. Oncogene 2018. [CrossRef]

106. Quail, D.F.; Joyce, J.A. Molecular Pathways: Deciphering Mechanisms of Resistance to Macrophage-Targeted Therapies. Clin. Cancer Res. 2017, 23, 876-884. [CrossRef]

107. Cassetta, L.; Pollard, J.W. Targeting macrophages: Therapeutic approaches in cancer. Nat. Rev. Drug Discov. 2018. [CrossRef]

108. Kumar, V.; Donthireddy, L.; Marvel, D.; Condamine, T.; Wang, F.; Lavilla-Alonso, S.; Hashimoto, A.; Vonteddu, P.; Behera, R.; Goins, M.A.; et al. Cancer-Associated Fibroblasts Neutralize the Anti-tumor Effect of CSF1 Receptor Blockade by Inducing PMN-MDSC Infiltration of Tumors. Cancer Cell 2017, 32, 654-668. [CrossRef]

109. Darby, I.A.; Hewitson, T.D. Fibroblast differentiation in wound healing and fibrosis. Int. Rev. Cytol. 2007, 257, 143-179.

110. Darby, I.A.; Laverdet, B.; Bonte, F.; Desmouliere, A. Fibroblasts and myofibroblasts in wound healing. Clin. Cosmet. Investig. Dermatol. 2014, 7, 301-311.

111. Penn, M.S. SDF-1:CXCR4 axis is fundamental for tissue preservation and repair. Am. J. Pathol. 2010, 177, 2166-2168. [CrossRef]

112. Schmidt, A.; Brixius, K.; Bloch, W. Endothelial precursor cell migration during vasculogenesis. Circ. Res. 2007, 101, 125-136. [CrossRef]

113. Sewell-Loftin, M.K.; Bayer, S.V.H.; Crist, E.; Hughes, T.; Joison, S.M.; Longmore, G.D.; George, S.C. Cancer-associated fibroblasts support vascular growth through mechanical force. Sci. Rep. 2017, 7, 12574. [CrossRef]

114. Fukumura, D.; Xavier, R.; Sugiura, T.; Chen, Y.; Park, E.C.; Lu, N.; Selig, M.; Nielsen, G.; Taksir, T.; Jain, R.K.; et al. Tumor induction of VEGF promoter activity in stromal cells. Cell 1998, 94, 715-725. [CrossRef]

115. Orimo, A.; Gupta, P.B.; Sgroi, D.C.; Arenzana-Seisdedos, F.; Delaunay, T.; Naeem, R.; Carey, V.J.; Richardson, A.L.; Weinberg, R.A. Stromal fibroblasts present in invasive human breast carcinomas promote tumor growth and angiogenesis through elevated SDF-1/CXCL12 secretion. Cell 2005, 121, 335-348. [CrossRef]

116. Calon, A.; Espinet, E.; Palomo-Ponce, S.; Tauriello, D.V.; Iglesias, M.; Cespedes, M.V.; Sevillano, M.; Nadal, C.; Jung, P.; Zhang, X.H.; et al. Dependency of colorectal cancer on a TGF-beta-driven program in stromal cells for metastasis initiation. Cancer Cell 2012, 22, 571-584. [CrossRef]

117. De Wever, O.; Westbroek, W.; Verloes, A.; Bloemen, N.; Bracke, M.; Gespach, C.; Bruyneel, E.; Mareel, M. Critical role of N-cadherin in myofibroblast invasion and migration in vitro stimulated by colon-cancer-cell-derived TGF-beta or wounding. J. Cell Sci. 2004, 117, 4691-4703. [CrossRef]

118. Ng, C.F.; Frieboes, H.B. Model of vascular desmoplastic multispecies tumor growth. J. Theor. Biol. 2017, 430, 245-282. [CrossRef]

119. Nishida, N.; Yano, H.; Nishida, T.; Kamura, T.; Kojiro, M. Angiogenesis in cancer. Vasc. Health Risk Manag. 2006, 2, 213-219. [CrossRef]

120. Izumi, D.; Ishimoto, T.; Miyake, K.; Sugihara, H.; Eto, K.; Sawayama, H.; Yasuda, T.; Kiyozumi, Y.; Kaida, T.; Kurashige, J.; et al. CXCL12/CXCR4 activation by cancer-associated fibroblasts promotes integrin beta1 clustering and invasiveness in gastric cancer. Int. J. Cancer 2016, 138, 1207-1219. [CrossRef]

121. Sun, X.; Cheng, G.; Hao, M.; Zheng, J.; Zhou, X.; Zhang, J.; Taichman, R.S.; Pienta, K.J.; Wang, J. CXCL12 / CXCR4 / CXCR7 chemokine axis and cancer progression. Cancer Metastasis Rev. 2010, 29, 709-722. [CrossRef]

122. Teng, F.; Tian, W.Y.; Wang, Y.M.; Zhang, Y.F.; Guo, F.; Zhao, J.; Gao, C.; Xue, F.X. Cancer-associated fibroblasts promote the progression of endometrial cancer via the SDF-1/CXCR4 axis. J. Hematol. Oncol. 2016, 9, 8. [CrossRef]

123. Jin, F.; Brockmeier, U.; Otterbach, F.; Metzen, E. New insight into the SDF-1/CXCR4 axis in a breast carcinoma model: Hypoxia-induced endothelial SDF-1 and tumor cell CXCR4 are required for tumor cell intravasation. Mol. Cancer Res. 2012, 10, 1021-1031. [CrossRef]

124. Mego, M.; Cholujova, D.; Minarik, G.; Sedlackova, T.; Gronesova, P.; Karaba, M.; Benca, J.; Cingelova, S.; Cierna, Z.; Manasova, D.; et al. CXCR4-SDF-1 interaction potentially mediates trafficking of circulating tumor cells in primary breast cancer. BMC Cancer 2016, 16, 127. [CrossRef] 
125. Fujii, H.; Biel, M.A.; Zhou, W.; Weitzman, S.A.; Baylin, S.B.; Gabrielson, E. Methylation of the HIC-1 candidate tumor suppressor gene in human breast cancer. Oncogene 1998, 16, 2159-2164. [CrossRef]

126. Wang, X.; Wang, Y.; Xiao, G.; Wang, J.; Zu, L.; Hao, M.; Sun, X.; Fu, Y.; Hu, G.; Wang, J. Hypermethylated in cancer 1(HIC1) suppresses non-small cell lung cancer progression by targeting interleukin-6/Stat3 pathway. Oncotarget 2016, 7, 30350-30364. [CrossRef]

127. Wang, Y.; Weng, X.; Wang, L.; Hao, M.; Li, Y.; Hou, L.; Liang, Y.; Wu, T.; Yao, M.; Lin, G.; et al. HIC1 deletion promotes breast cancer progression by activating tumor cell/fibroblast crosstalk. J. Clin. Investig. 2018. [CrossRef]

128. Zheng, J.; Wang, J.; Sun, X.; Hao, M.; Ding, T.; Xiong, D.; Wang, X.; Zhu, Y.; Xiao, G.; Cheng, G.; et al. HIC1 modulates prostate cancer progression by epigenetic modification. Clin. Cancer Res. 2013, 19, 1400-1410. [CrossRef]

129. Gaggioli, C.; Hooper, S.; Hidalgo-Carcedo, C.; Grosse, R.; Marshall, J.F.; Harrington, K.; Sahai, E. Fibroblast-led collective invasion of carcinoma cells with differing roles for RhoGTPases in leading and following cells. Nat. Cell Biol. 2007, 9, 1392-1400. [CrossRef]

130. Grasset, E.M.; Bertero, T.; Bozec, A.; Friard, J.; Bourget, I.; Pisano, S.; Lecacheur, M.; Maiel, M.; Bailleux, C.; Emelyanov, A.; et al. Matrix Stiffening and EGFR Cooperate to Promote the Collective Invasion of Cancer Cells. Cancer Res. 2018, 78, 5229-5242. [CrossRef]

131. Mani, S.A.; Guo, W.; Liao, M.J.; Eaton, E.N.; Ayyanan, A.; Zhou, A.Y.; Brooks, M.; Reinhard, F.; Zhang, C.C.; Shipitsin, M.; et al. The epithelial-mesenchymal transition generates cells with properties of stem cells. Cell 2008, 133, 704-715. [CrossRef]

132. Shibue, T.; Weinberg, R.A. EMT, CSCs, and drug resistance: The mechanistic link and clinical implications. Nat. Rev. Clin. Oncol. 2017, 14, 611-629. [CrossRef]

133. Saitoh, M. Involvement of partial EMT in cancer progression. J. Biochem. 2018, 164, 257-264. [CrossRef]

134. Nieto, M.A.; Huang, R.Y.; Jackson, R.A.; Thiery, J.P. Emt: 2016. Cell 2016, 166, 21-45. [CrossRef]

135. Krebs, A.M.; Mitschke, J.; Lasierra Losada, M.; Schmalhofer, O.; Boerries, M.; Busch, H.; Boettcher, M.; Mougiakakos, D.; Reichardt, W.; Bronsert, P.; et al. The EMT-activator Zeb1 is a key factor for cell plasticity and promotes metastasis in pancreatic cancer. Nat. Cell Biol. 2017, 19, 518-529. [CrossRef]

136. Byrne, C.; Schairer, C.; Wolfe, J.; Parekh, N.; Salane, M.; Brinton, L.A.; Hoover, R.; Haile, R. Mammographic features and breast cancer risk: Effects with time, age, and menopause status. J. Natl. Cancer Inst. 1995, 87, 1622-1629. [CrossRef]

137. DeFilippis, R.A.; Chang, H.; Dumont, N.; Rabban, J.T.; Chen, Y.Y.; Fontenay, G.V.; Berman, H.K.; Gauthier, M.L.; Zhao, J.; Hu, D.; et al. CD36 repression activates a multicellular stromal program shared by high mammographic density and tumor tissues. Cancer Discov. 2012, 2, 826-839. [CrossRef]

138. Plikus, M.V.; Guerrero-Juarez, C.F.; Ito, M.; Li, Y.R.; Dedhia, P.H.; Zheng, Y.; Shao, M.; Gay, D.L.; Ramos, R.; Hsi, T.C.; et al. Regeneration of fat cells from myofibroblasts during wound healing. Science 2017, 355, 748-752. [CrossRef]

139. Thomson, D.M.; Winder, W.W. AMP-activated protein kinase control of fat metabolism in skeletal muscle. Acta Physiol. 2009, 196, 147-154. [CrossRef]

140. Ladanyi, A.; Mukherjee, A.; Kenny, H.A.; Johnson, A.; Mitra, A.K.; Sundaresan, S.; Nieman, K.M.; Pascual, G.; Benitah, S.A.; Montag, A.; et al. Adipocyte-induced CD36 expression drives ovarian cancer progression and metastasis. Oncogene 2018, 37, 2285-2301. [CrossRef]

141. Pascual, G.; Avgustinova, A.; Mejetta, S.; Martin, M.; Castellanos, A.; Attolini, C.S.; Berenguer, A.; Prats, N.; Toll, A.; Hueto, J.A.; et al. Targeting metastasis-initiating cells through the fatty acid receptor CD36. Nature 2017, 541, 41-45. [CrossRef]

142. Martinez-Outschoorn, U.E.; Sotgia, F.; Lisanti, M.P. Caveolae and signalling in cancer. Nat. Rev. Cancer 2015, 15, 225-237. [CrossRef]

143. Santi, A.; Kugeratski, F.G.; Zanivan, S. Cancer Associated Fibroblasts: The Architects of Stroma Remodeling. Proteomics 2018, 18, e1700167. [CrossRef]

144. Whitaker-Menezes, D.; Martinez-Outschoorn, U.E.; Lin, Z.; Ertel, A.; Flomenberg, N.; Witkiewicz, A.K.; Birbe, R.C.; Howell, A.; Pavlides, S.; Gandara, R.; et al. Evidence for a stromal-epithelial "lactate shuttle" in human tumors: MCT4 is a marker of oxidative stress in cancer-associated fibroblasts. Cell Cycle 2011, 10, 1772-1783. [CrossRef] 
145. Yoshida, G.J. Metabolic reprogramming: The emerging concept and associated therapeutic strategies. J. Exp. Clin. Cancer Res. 2015, 34, 111. [CrossRef]

146. Liberti, M.V.; Locasale, J.W. The Warburg Effect: How Does it Benefit Cancer Cells? Trends Biochem. Sci. 2016, 41, 211-218. [CrossRef]

147. Schwartz, L.; Supuran, C.T.; Alfarouk, K.O. The Warburg Effect and the Hallmarks of Cancer. Anticancer Agents Med. Chem. 2017, 17, 164-170. [CrossRef]

148. Warburg, O. On the origin of cancer cells. Science 1956, 123, 309-314. [CrossRef]

149. Fu, Y.; Liu, S.; Yin, S.; Niu, W.; Xiong, W.; Tan, M.; Li, G.; Zhou, M. The reverse Warburg effect is likely to be an Achilles' heel of cancer that can be exploited for cancer therapy. Oncotarget 2017, 8, 57813-57825. [CrossRef]

150. Pavlides, S.; Whitaker-Menezes, D.; Castello-Cros, R.; Flomenberg, N.; Witkiewicz, A.K.; Frank, P.G.; Casimiro, M.C.; Wang, C.; Fortina, P.; Addya, S.; et al. The reverse Warburg effect: Aerobic glycolysis in cancer associated fibroblasts and the tumor stroma. Cell Cycle 2009, 8, 3984-4001. [CrossRef]

151. Jezierska-Drutel, A.; Rosenzweig, S.A.; Neumann, C.A. Role of oxidative stress and the microenvironment in breast cancer development and progression. Adv. Cancer Res. 2013, 119, 107-125.

152. Mougeolle, A.; Poussard, S.; Decossas, M.; Lamaze, C.; Lambert, O.; Dargelos, E. Oxidative stress induces caveolin 1 degradation and impairs caveolae functions in skeletal muscle cells. PLoS ONE 2015, 10, e0122654. [CrossRef]

153. Wang, S.; Wang, N.; Zheng, Y.; Zhang, J.; Zhang, F.; Wang, Z. Caveolin-1: An Oxidative Stress-Related Target for Cancer Prevention. Oxid. Med. Cell Longev. 2017, 2017, 7454031. [CrossRef]

154. Avagliano, A.; Granato, G.; Ruocco, M.R.; Romano, V.; Belviso, I.; Carfora, A.; Montagnani, S.; Arcucci, A. Metabolic Reprogramming of Cancer Associated Fibroblasts: The Slavery of Stromal Fibroblasts. Biomed. Res. Int. 2018, 2018, 6075403. [CrossRef]

155. Pavlides, S.; Vera, I.; Gandara, R.; Sneddon, S.; Pestell, R.G.; Mercier, I.; Martinez-Outschoorn, U.E.; Whitaker-Menezes, D.; Howell, A.; Sotgia, F.; et al. Warburg meets autophagy: Cancer-associated fibroblasts accelerate tumor growth and metastasis via oxidative stress, mitophagy, and aerobic glycolysis. Antioxid. Redox Signal. 2012, 16, 1264-1284. [CrossRef]

156. Xing, Y.; Zhao, S.; Zhou, B.P.; Mi, J. Metabolic reprogramming of the tumour microenvironment. FEBS J. 2015, 282, 3892-3898. [CrossRef]

157. Capparelli, C.; Guido, C.; Whitaker-Menezes, D.; Bonuccelli, G.; Balliet, R.; Pestell, T.G.; Goldberg, A.F.; Pestell, R.G.; Howell, A.; Sneddon, S.; et al. Autophagy and senescence in cancer-associated fibroblasts metabolically supports tumor growth and metastasis via glycolysis and ketone production. Cell Cycle 2012, 11, 2285-2302. [CrossRef]

158. Allen, E.; Mieville, P.; Warren, C.M.; Saghafinia, S.; Li, L.; Peng, M.W.; Hanahan, D. Metabolic Symbiosis Enables Adaptive Resistance to Anti-angiogenic Therapy that Is Dependent on mTOR Signaling. Cell Rep. 2016, 15, 1144-1160. [CrossRef]

159. Porporato, P.E.; Dhup, S.; Dadhich, R.K.; Copetti, T.; Sonveaux, P. Anticancer targets in the glycolytic metabolism of tumors: A comprehensive review. Front. Pharmacol. 2011, 2, 49. [CrossRef]

160. Semenza, G.L. Tumor metabolism: Cancer cells give and take lactate. J. Clin. Investig. 2008, 118, 3835-3837. [CrossRef]

161. Sonveaux, P.; Vegran, F.; Schroeder, T.; Wergin, M.C.; Verrax, J.; Rabbani, Z.N.; De Saedeleer, C.J.; Kennedy, K.M.; Diepart, C.; Jordan, B.F.; et al. Targeting lactate-fueled respiration selectively kills hypoxic tumor cells in mice. J. Clin. Investig. 2008, 118, 3930-3942. [CrossRef]

162. Linares, J.F.; Cordes, T.; Duran, A.; Reina-Campos, M.; Valencia, T.; Ahn, C.S.; Castilla, E.A.; Moscat, J.; Metallo, C.M.; Diaz-Meco, M.T. ATF4-Induced Metabolic Reprograming Is a Synthetic Vulnerability of the p62-Deficient Tumor Stroma. Cell Metab. 2017, 26, 817-829. [CrossRef]

163. Duran, A.; Hernandez, E.D.; Reina-Campos, M.; Castilla, E.A.; Subramaniam, S.; Raghunandan, S.; Roberts, L.R.; Kisseleva, T.; Karin, M.; Diaz-Meco, M.T.; et al. p62/SQSTM1 by Binding to Vitamin D Receptor Inhibits Hepatic Stellate Cell Activity, Fibrosis, and Liver Cancer. Cancer Cell 2016, 30, 595-609. [CrossRef]

164. Reina-Campos, M.; Shelton, P.M.; Diaz-Meco, M.T.; Moscat, J. Metabolic reprogramming of the tumor microenvironment by p62 and its partners. Biochim. Biophys. Acta Rev. Cancer 2018, 1870, 88-95. [CrossRef]

165. Goruppi, S.; Jo, S.H.; Laszlo, C.; Clocchiatti, A.; Neel, V.; Dotto, G.P. Autophagy Controls CSL/RBPJkappa Stability through a p62/SQSTM1-Dependent Mechanism. Cell Rep. 2018, 24, 3108-3114. [CrossRef] 
166. Valencia, T.; Kim, J.Y.; Abu-Baker, S.; Moscat-Pardos, J.; Ahn, C.S.; Reina-Campos, M.; Duran, A.; Castilla, E.A.; Metallo, C.M.; Diaz-Meco, M.T.; et al. Metabolic reprogramming of stromal fibroblasts through p62-mTORC1 signaling promotes inflammation and tumorigenesis. Cancer Cell 2014, 26, 121-135. [CrossRef]

167. Mizushima, N.; Komatsu, M. Autophagy: Renovation of cells and tissues. Cell 2011, 147, 728-741. [CrossRef]

168. Moscat, J.; Diaz-Meco, M.T. p62 at the crossroads of autophagy, apoptosis, and cancer. Cell 2009, 137, 1001-1004. [CrossRef]

169. Huang, J.; Diaz-Meco, M.T.; Moscat, J. The macroenviromental control of cancer metabolism by p62. Cell Cycle 2018, 17, 2110-2121. [CrossRef]

170. Jain, R.K.; Tong, R.T.; Munn, L.L. Effect of vascular normalization by antiangiogenic therapy on interstitial hypertension, peritumor edema, and lymphatic metastasis: Insights from a mathematical model. Cancer Res. 2007, 67, 2729-2735. [CrossRef]

171. Munson, J.M.; Shieh, A.C. Interstitial fluid flow in cancer: Implications for disease progression and treatment. Cancer Manag. Res. 2014, 6, 317-328. [CrossRef]

172. Omidi, Y.; Barar, J. Targeting tumor microenvironment: Crossing tumor interstitial fluid by multifunctional nanomedicines. Bioimpacts 2014, 4, 55-67.

173. Kerbel, R.S. Tumor angiogenesis. N. Engl. J. Med. 2008, 358, 2039-2049. [CrossRef]

174. Christian, S.; Winkler, R.; Helfrich, I.; Boos, A.M.; Besemfelder, E.; Schadendorf, D.; Augustin, H.G. Endosialin (Tem1) is a marker of tumor-associated myofibroblasts and tumor vessel-associated mural cells. Am. J. Pathol. 2008, 172, 486-494. [CrossRef]

175. Otranto, M.; Sarrazy, V.; Bonte, F.; Hinz, B.; Gabbiani, G.; Desmouliere, A. The role of the myofibroblast in tumor stroma remodeling. Cell Adhes. Migr. 2012, 6, 203-219. [CrossRef]

176. Ribeiro, A.L.; Okamoto, O.K. Combined effects of pericytes in the tumor microenvironment. Stem Cells Int. 2015, 2015, 868475. [CrossRef]

177. Liao, Z.; Tan, Z.W.; Zhu, P.; Tan, N.S. Cancer-associated fibroblasts in tumor microenvironment-Accomplices in tumor malignancy. Cell Immunol. 2018. [CrossRef]

178. Boucher, Y.; Salehi, H.; Witwer, B.; Harsh, G.R.T.; Jain, R.K. Interstitial fluid pressure in intracranial tumours in patients and in rodents. Br. J. Cancer 1997, 75, 829-836. [CrossRef]

179. Nathanson, S.D.; Nelson, L. Interstitial fluid pressure in breast cancer, benign breast conditions, and breast parenchyma. Ann. Surg. Oncol. 1994, 1, 333-338. [CrossRef]

180. Simonsen, T.G.; Gaustad, J.V.; Leinaas, M.N.; Rofstad, E.K. High interstitial fluid pressure is associated with tumor-line specific vascular abnormalities in human melanoma xenografts. PLoS ONE 2012, 7, e40006. [CrossRef]

181. Bhome, R.; Al Saihati, H.A.; Goh, R.W.; Bullock, M.D.; Primrose, J.N.; Thomas, G.J.; Sayan, A.E.; Mirnezami, A.H. Translational aspects in targeting the stromal tumour microenvironment: From bench to bedside. New Horiz Transl. Med. 2016, 3, 9-21. [CrossRef]

182. Cazet, A.S.; Hui, M.N.; Elsworth, B.L.; Wu, S.Z.; Roden, D.; Chan, C.L.; Skhinas, J.N.; Collot, R.; Yang, J.; Harvey, K.; et al. Targeting stromal remodeling and cancer stem cell plasticity overcomes chemoresistance in triple negative breast cancer. Nat. Commun. 2018, 9, 2897. [CrossRef]

183. Giussani, M.; Merlino, G.; Cappelletti, V.; Tagliabue, E.; Daidone, M.G. Tumor-extracellular matrix interactions: Identification of tools associated with breast cancer progression. Semin. Cancer Biol. 2015, 35, 3-10. [CrossRef]

184. Son, B.; Lee, S.; Youn, H.; Kim, E.; Kim, W.; Youn, B. The role of tumor microenvironment in therapeutic resistance. Oncotarget 2017, 8, 3933-3945. [CrossRef]

185. Levental, K.R.; Yu, H.; Kass, L.; Lakins, J.N.; Egeblad, M.; Erler, J.T.; Fong, S.F.; Csiszar, K.; Giaccia, A.; Weninger, W.; et al. Matrix crosslinking forces tumor progression by enhancing integrin signaling. Cell 2009, 139, 891-906. [CrossRef]

186. Peng, C.; Liu, J.; Yang, G.; Li, Y. Lysyl oxidase activates cancer stromal cells and promotes gastric cancer progression: Quantum dot-based identification of biomarkers in cancer stromal cells. Int. J. Nanomed. 2018, 13, 161-174. [CrossRef]

187. Wang, T.H.; Hsia, S.M.; Shieh, T.M. Lysyl Oxidase and the Tumor Microenvironment. Int. J. Mol. Sci. 2016, 18, 62. [CrossRef]

188. Reynaud, C.; Ferreras, L.; Di Mauro, P.; Kan, C.; Croset, M.; Bonnelye, E.; Pez, F.; Thomas, C.; Aimond, G.; Karnoub, A.E.; et al. Lysyl Oxidase Is a Strong Determinant of Tumor Cell Colonization in Bone. Cancer Res. 2017, 77, 268-278. [CrossRef] 
189. Cox, T.R.; Gartland, A.; Erler, J.T. Lysyl Oxidase, a Targetable Secreted Molecule Involved in Cancer Metastasis. Cancer Res. 2016, 76, 188-192. [CrossRef]

190. Miller, B.W.; Morton, J.P.; Pinese, M.; Saturno, G.; Jamieson, N.B.; McGhee, E.; Timpson, P.; Leach, J.; McGarry, L.; Shanks, E.; et al. Targeting the LOX/hypoxia axis reverses many of the features that make pancreatic cancer deadly: Inhibition of LOX abrogates metastasis and enhances drug efficacy. EMBO Mol. Med. 2015, 7, 1063-1076. [CrossRef]

191. Kelleher, F.C. Hedgehog signaling and therapeutics in pancreatic cancer. Carcinogenesis 2011, 32, $445-451$. [CrossRef]

192. Erkan, M.; Hausmann, S.; Michalski, C.W.; Fingerle, A.A.; Dobritz, M.; Kleeff, J.; Friess, H. The role of stroma in pancreatic cancer: Diagnostic and therapeutic implications. Nat. Rev. Gastroenterol. Hepatol. 2012, 9, 454-467. [CrossRef]

193. Mathew, E.; Zhang, Y.; Holtz, A.M.; Kane, K.T.; Song, J.Y.; Allen, B.L.; Pasca di Magliano, M. Dosage-dependent regulation of pancreatic cancer growth and angiogenesis by hedgehog signaling. Cell Rep. 2014, 9, 484-494. [CrossRef]

194. Olive, K.P.; Jacobetz, M.A.; Davidson, C.J.; Gopinathan, A.; McIntyre, D.; Honess, D.; Madhu, B.; Goldgraben, M.A.; Caldwell, M.E.; Allard, D.; et al. Inhibition of Hedgehog signaling enhances delivery of chemotherapy in a mouse model of pancreatic cancer. Science 2009, 324, 1457-1461. [CrossRef]

195. Jiang, Z.; Zhou, C.; Cheng, L.; Yan, B.; Chen, K.; Chen, X.; Zong, L.; Lei, J.; Duan, W.; Xu, Q.; et al. Inhibiting YAP expression suppresses pancreatic cancer progression by disrupting tumor-stromal interactions. J. Exp. Clin. Cancer Res. 2018, 37, 69. [CrossRef]

196. Kharaishvili, G.; Simkova, D.; Bouchalova, K.; Gachechiladze, M.; Narsia, N.; Bouchal, J. The role of cancer-associated fibroblasts, solid stress and other microenvironmental factors in tumor progression and therapy resistance. Cancer Cell Int. 2014, 14, 41. [CrossRef]

197. Warren, J.S.A.; Xiao, Y.; Lamar, J.M. YAP/TAZ Activation as a Target for Treating Metastatic Cancer. Cancers 2018, 10, 115. [CrossRef]

198. Calvo, F.; Ege, N.; Grande-Garcia, A.; Hooper, S.; Jenkins, R.P.; Chaudhry, S.I.; Harrington, K.; Williamson, P.; Moeendarbary, E.; Charras, G.; et al. Mechanotransduction and YAP-dependent matrix remodelling is required for the generation and maintenance of cancer-associated fibroblasts. Nat. Cell Biol. 2013, 15, 637-646. [CrossRef]

199. Campbell, I.; Polyak, K.; Haviv, I. Clonal mutations in the cancer-associated fibroblasts: The case against genetic coevolution. Cancer Res. 2009, 69, 6765-6768, discussion 6769. [CrossRef]

200. Togo, S.; Polanska, U.M.; Horimoto, Y.; Orimo, A. Carcinoma-associated fibroblasts are a promising therapeutic target. Cancers 2013, 5, 149-169. [CrossRef]

201. Hanahan, D.; Coussens, L.M. Accessories to the crime: Functions of cells recruited to the tumor microenvironment. Cancer Cell 2012, 21, 309-322. [CrossRef]

202. Tredan, O.; Galmarini, C.M.; Patel, K.; Tannock, I.F. Drug resistance and the solid tumor microenvironment. J. Natl. Cancer Inst. 2007, 99, 1441-1454. [CrossRef]

203. Wu, M.; Frieboes, H.B.; Chaplain, M.A.; McDougall, S.R.; Cristini, V.; Lowengrub, J.S. The effect of interstitial pressure on therapeutic agent transport: Coupling with the tumor blood and lymphatic vascular systems. J. Theor. Biol. 2014, 355, 194-207. [CrossRef]

204. Gourd, E. PEGPH20 for metastatic pancreatic ductal adenocarcinoma. Lancet Oncol. 2018, 19, e81. [CrossRef]

205. Michl, P.; Gress, T.M. Improving drug delivery to pancreatic cancer: Breaching the stromal fortress by targeting hyaluronic acid. Gut 2012, 61, 1377-1379. [CrossRef]

206. Provenzano, P.P.; Cuevas, C.; Chang, A.E.; Goel, V.K.; Von Hoff, D.D.; Hingorani, S.R. Enzymatic targeting of the stroma ablates physical barriers to treatment of pancreatic ductal adenocarcinoma. Cancer Cell 2012, 21, 418-429. [CrossRef]

207. Hingorani, S.R.; Zheng, L.; Bullock, A.J.; Seery, T.E.; Harris, W.P.; Sigal, D.S.; Braiteh, F.; Ritch, P.S.; Zalupski, M.M.; Bahary, N.; et al. HALO 202: Randomized Phase II Study of PEGPH20 Plus Nab-Paclitaxel/Gemcitabine Versus Nab-Paclitaxel/Gemcitabine in Patients With Untreated, Metastatic Pancreatic Ductal Adenocarcinoma. J. Clin. Oncol. 2018, 36, 359-366. [CrossRef]

208. Evans, J.M.; Donnelly, L.A.; Emslie-Smith, A.M.; Alessi, D.R.; Morris, A.D. Metformin and reduced risk of cancer in diabetic patients. BMJ 2005, 330, 1304-1305. [CrossRef] 
209. Kourelis, T.V.; Siegel, R.D. Metformin and cancer: New applications for an old drug. Med. Oncol. 2012, 29, 1314-1327. [CrossRef]

210. Leone, A.; Di Gennaro, E.; Bruzzese, F.; Avallone, A.; Budillon, A. New perspective for an old antidiabetic drug: Metformin as anticancer agent. Cancer Treat. Res. 2014, 159, 355-376.

211. Saini, N.; Yang, X. Metformin as an anti-cancer agent: Actions and mechanisms targeting cancer stem cells. Acta Biochim. Biophys. Sin. 2018, 50, 133-143. [CrossRef]

212. Yoshida, G.J. Therapeutic strategies of drug repositioning targeting autophagy to induce cancer cell death: From pathophysiology to treatment. J. Hematol. Oncol. 2017, 10, 67. [CrossRef]

213. Nesti, L.; Natali, A. Metformin effects on the heart and the cardiovascular system: A review of experimental and clinical data. Nutr. Metab. Cardiovasc. Dis. 2017, 27, 657-669. [CrossRef]

214. Rangarajan, S.; Bone, N.B.; Zmijewska, A.A.; Jiang, S.; Park, D.W.; Bernard, K.; Locy, M.L.; Ravi, S.; Deshane, J.; Mannon, R.B.; et al. Metformin reverses established lung fibrosis in a bleomycin model. Nat. Med. 2018, 24, 1121-1127. [CrossRef]

215. Shao, R.; Li, X.; Feng, Y.; Lin, J.F.; Billig, H. Direct effects of metformin in the endometrium: A hypothetical mechanism for the treatment of women with PCOS and endometrial carcinoma. J. Exp. Clin. Cancer Res. 2014, 33, 41. [CrossRef]

216. Yi, H.; Huang, C.; Shi, Y.; Cao, Q.; Zhao, Y.; Zhang, L.; Chen, J.; Pollock, C.A.; Chen, X.M. Metformin attenuates folic-acid induced renal fibrosis in mice. J. Cell Physiol. 2018, 233, 7045-7054. [CrossRef]

217. Li, L.; Huang, W.; Li, K.; Zhang, K.; Lin, C.; Han, R.; Lu, C.; Wang, Y.; Chen, H.; Sun, F.; et al. Metformin attenuates gefitinib-induced exacerbation of pulmonary fibrosis by inhibition of TGF-beta signaling pathway. Oncotarget 2015, 6, 43605-43619. [CrossRef]

218. Xu, S.; Yang, Z.; Jin, P.; Yang, X.; Li, X.; Wei, X.; Wang, Y.; Long, S.; Zhang, T.; Chen, G.; et al. Metformin Suppresses Tumor Progression by Inactivating Stromal Fibroblasts in Ovarian Cancer. Mol. Cancer Ther. 2018, 17, 1291-1302. [CrossRef]

219. Pinter, M.; Jain, R.K. Targeting the renin-angiotensin system to improve cancer treatment: Implications for immunotherapy. Sci. Transl. Med. 2017, 9, eaan5616. [CrossRef]

220. Chauhan, V.P.; Martin, J.D.; Liu, H.; Lacorre, D.A.; Jain, S.R.; Kozin, S.V.; Stylianopoulos, T.; Mousa, A.S.; Han, X.; Adstamongkonkul, P.; et al. Angiotensin inhibition enhances drug delivery and potentiates chemotherapy by decompressing tumour blood vessels. Nat. Commun. 2013, 4, 2516. [CrossRef]

221. Vennin, C.; Murphy, K.J.; Morton, J.P.; Cox, T.R.; Pajic, M.; Timpson, P. Reshaping the Tumor Stroma for Treatment of Pancreatic Cancer. Gastroenterology 2018, 154, 820-838. [CrossRef]

222. Azuma, A. Pirfenidone treatment of idiopathic pulmonary fibrosis. Ther. Adv. Respir. Dis. 2012, 6, 107-114. [CrossRef]

223. Didiasova, M.; Singh, R.; Wilhelm, J.; Kwapiszewska, G.; Wujak, L.; Zakrzewicz, D.; Schaefer, L.; Markart, P.; Seeger, W.; Lauth, M.; et al. Pirfenidone exerts antifibrotic effects through inhibition of GLI transcription factors. FASEB J. 2017, 31, 1916-1928. [CrossRef]

224. Miura, Y.; Saito, T.; Tanaka, T.; Takoi, H.; Yatagai, Y.; Inomata, M.; Nei, T.; Saito, Y.; Gemma, A.; Azuma, A. Reduced incidence of lung cancer in patients with idiopathic pulmonary fibrosis treated with pirfenidone. Respir. Investig. 2018, 56, 72-79. [CrossRef]

225. Mediavilla-Varela, M.; Boateng, K.; Noyes, D.; Antonia, S.J. The anti-fibrotic agent pirfenidone synergizes with cisplatin in killing tumor cells and cancer-associated fibroblasts. BMC Cancer 2016, 16, 176. [CrossRef]

226. Ke, Z.; He, W.; Lai, Y.; Guo, X.; Chen, S.; Li, S.; Wang, Y.; Wang, L. Overexpression of collagen triple helix repeat containing 1 (CTHRC1) is associated with tumour aggressiveness and poor prognosis in human non-small cell lung cancer. Oncotarget 2014, 5, 9410-9424. [CrossRef]

227. Takai, K.; Le, A.; Weaver, V.M.; Werb, Z. Targeting the cancer-associated fibroblasts as a treatment in triple-negative breast cancer. Oncotarget 2016, 7, 82889-82901. [CrossRef]

228. Kozono, S.; Ohuchida, K.; Eguchi, D.; Ikenaga, N.; Fujiwara, K.; Cui, L.; Mizumoto, K.; Tanaka, M. Pirfenidone inhibits pancreatic cancer desmoplasia by regulating stellate cells. Cancer Res. 2013, 73, 2345-2356. [CrossRef]

229. Polydorou, C.; Mpekris, F.; Papageorgis, P.; Voutouri, C.; Stylianopoulos, T. Pirfenidone normalizes the tumor microenvironment to improve chemotherapy. Oncotarget 2017, 8, 24506-24517. [CrossRef]

230. Ding, N.; Hah, N.; Yu, R.T.; Sherman, M.H.; Benner, C.; Leblanc, M.; He, M.; Liddle, C.; Downes, M.; Evans, R.M. BRD4 is a novel therapeutic target for liver fibrosis. Proc. Natl. Acad. Sci. USA 2015, 112, 15713-15718. [CrossRef] 
231. Yamamoto, K.; Tateishi, K.; Kudo, Y.; Hoshikawa, M.; Tanaka, M.; Nakatsuka, T.; Fujiwara, H.; Miyabayashi, K.; Takahashi, R.; Tanaka, Y.; et al. Stromal remodeling by the BET bromodomain inhibitor JQ1 suppresses the progression of human pancreatic cancer. Oncotarget 2016, 7, 61469-61484. [CrossRef]

232. Middleton, S.A.; Rajpal, N.; Cutler, L.; Mander, P.; Rioja, I.; Prinjha, R.K.; Rajpal, D.; Agarwal, P.; Kumar, V. BET Inhibition Improves NASH and Liver Fibrosis. Sci. Rep. 2018, 8, 17257. [CrossRef]

233. Kim, D.E.; Procopio, M.G.; Ghosh, S.; Jo, S.H.; Goruppi, S.; Magliozzi, F.; Bordignon, P.; Neel, V.; Angelino, P.; Dotto, G.P. Convergent roles of ATF3 and CSL in chromatin control of cancer-associated fibroblast activation. J. Exp. Med. 2017, 214, 2349-2368. [CrossRef]

234. Hah, N.; Sherman, M.H.; Yu, R.T.; Downes, M.; Evans, R.M. Targeting Transcriptional and Epigenetic Reprogramming in Stromal Cells in Fibrosis and Cancer. Cold Spring Harb. Symp. Quant. Biol. 2015, 80, 249-255. [CrossRef]

235. Ding, N.; Yu, R.T.; Subramaniam, N.; Sherman, M.H.; Wilson, C.; Rao, R.; Leblanc, M.; Coulter, S.; He, M.; Scott, C.; et al. A vitamin D receptor/SMAD genomic circuit gates hepatic fibrotic response. Cell 2013, 153, 601-613. [CrossRef]

236. Sherman, M.H.; Yu, R.T.; Engle, D.D.; Ding, N.; Atkins, A.R.; Tiriac, H.; Collisson, E.A.; Connor, F.; Van Dyke, T.; Kozlov, S.; et al. Vitamin D receptor-mediated stromal reprogramming suppresses pancreatitis and enhances pancreatic cancer therapy. Cell 2014, 159, 80-93. [CrossRef]

237. Shin, K.; Lim, A.; Zhao, C.; Sahoo, D.; Pan, Y.; Spiekerkoetter, E.; Liao, J.C.; Beachy, P.A. Hedgehog signaling restrains bladder cancer progression by eliciting stromal production of urothelial differentiation factors. Cancer Cell 2014, 26, 521-533. [CrossRef]

238. Ozdemir, B.C.; Pentcheva-Hoang, T.; Carstens, J.L.; Zheng, X.; Wu, C.C.; Simpson, T.R.; Laklai, H.; Sugimoto, H.; Kahlert, C.; Novitskiy, S.V.; et al. Depletion of carcinoma-associated fibroblasts and fibrosis induces immunosuppression and accelerates pancreas cancer with reduced survival. Cancer Cell 2014, 25, 719-734. [CrossRef]

239. Rhim, A.D.; Oberstein, P.E.; Thomas, D.H.; Mirek, E.T.; Palermo, C.F.; Sastra, S.A.; Dekleva, E.N.; Saunders, T.; Becerra, C.P.; Tattersall, I.W.; et al. Stromal elements act to restrain, rather than support, pancreatic ductal adenocarcinoma. Cancer Cell 2014, 25, 735-747. [CrossRef]

240. Gerling, M.; Buller, N.V.; Kirn, L.M.; Joost, S.; Frings, O.; Englert, B.; Bergstrom, A.; Kuiper, R.V.; Blaas, L.; Wielenga, M.C.; et al. Stromal Hedgehog signalling is downregulated in colon cancer and its restoration restrains tumour growth. Nat. Commun. 2016, 7, 12321. [CrossRef]

241. Madar, S.; Goldstein, I.; Rotter, V. 'Cancer associated fibroblasts'—More than meets the eye. Trends Mol. Med. 2013, 19, 447-453. [CrossRef]

(C) 2019 by the authors. Licensee MDPI, Basel, Switzerland. This article is an open access article distributed under the terms and conditions of the Creative Commons Attribution (CC BY) license (http://creativecommons.org/licenses/by/4.0/). 